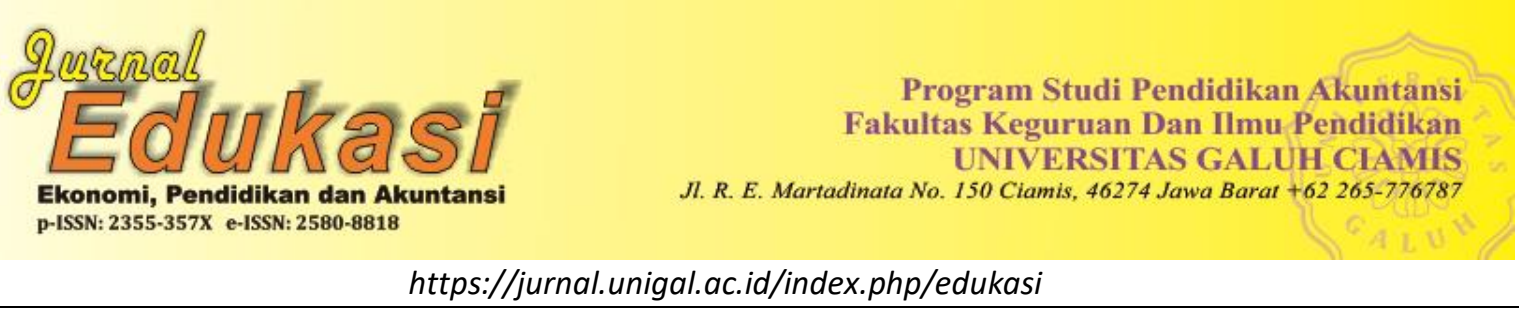

\title{
PERSEPSI MAHASISWA STIE SUTAATMADJA TERHADAP DIMENSI KUALITAS PELAYANAN BANDARA
}

\author{
Oleh: \\ Dena Nursya'adah ${ }^{1}$, Asep Kurniawan ${ }^{2}$ \\ Program Studi Akuntansi Sekolah Tinggi Ilmu Ekonomi Sutaatmadja, Indonesia \\ Email : denanursyaadah203@gmail.com \\ Email : asep@stiesa.ac.id \\ Sejarah Artikel: Diterima September 2019, Disetujui Oktober 2019, Dipublikasikan November 2019
}

\begin{abstract}
ABSTRAK
Perubahan sistem nilai pelayanan jasa penerbangan saat ini ditandai dengan fenomena bahwa pengguna jasa penerbangan tidak hanya menginginkan sekedar sampai tempat tujuan, namun juga menginginkan pelayanan dan pengalaman di bandara yang memuaskan. Penelitian yang dilakukan bertujuan untuk mengetahui persepsi penumpang dalam menilai setiap atribut dimensi kualitas pelayanan bandara yang diukur berdasarkan tujuh dimensi kualitas (akses bandara, layanan dan fasilitas bandara, fasilitas restoran bandara, fasilitas belanja bandara, personil layanan dan keamanan bandara, lingkungan bandara dan layanan imigrasi dan bea cukai) terhadap kualitas Soekarno Hatta International Airport (SHIA) dan Kuala Lumpur International Airport dua (KLIA II). Jenis penelitian yang digunakan yaitu kuantitatif deskriptif dengan instrumen penelitian kuesioner. Sampel dalam penelitian ini yaitu mahasiswa peserta KKL STIE Sutaatmadja. Teknik analisis data yang digunakan adalah uji validitas dan reliabilitas, uji asumsi klasik dan uji hipotesis (uji t dan uji f). Hasil uji hipotesis secara parsial menunjukan dari ketujuh dimensi kualitas untuk SHIA terdapat tiga dimensi kualitas yang berpengaruh positif signifikan terhadap evaluasi layanan bandara diantaranya kualitas akses bandara, lingkungan bandara dan layanan imigrasi dan bea cukai. Untuk KLIA II terdapat tiga dimensi kualitas yang berpengaruh positif signifikan terhadap evaluasi layanan bandara diantaranya kualitas layanan dan fasilitas bandara, personil layanan dan keamanan bandara dan layanan imigrasi dan bea cukai. Kemudian secara simultan baik untuk SHIA maupun KLIA II, ketujuh dimensi kualitas berpengaruh positif signifikan terhadap evaluasi layanan.
\end{abstract}

Kata Kunci: Kualitas Pelayanan, Persepsi, Kepuasan Pelanggan

\section{ABSTRACK}

Changes in the value system of flight services, currently characterized by the phenomenon that users of flight services not only want to get their destination, but also want a satisfying service and experience at the airport. The research aims to determine passenger perceptions in evaluate each attribute of airport service quality dimensions, which is measured based on seven quality dimensions (airport access, airport services and facilities, airport restaurant facilities, airport shopping facilities, airport service and security personnel, airport environment and immigration services and customs) of the quality of Soekarno Hatta International Airport (SHIA) and Kuala Lumpur International Airport two (KLIA II). The type of research is quantitative descriptive with a questionnaire research instrument. The population in this study were students participating in the KKL STIE Sutaatmadja. Data analysis techniques used are the validity and reliability test, the classic assumption test and the hypothesis test ( $t$-test and f-test). The result of partial hypothesis test for SHIA, there are three of seven quality dimensions that have a significant positive effect on the evaluation of airport services, including airport access quality, airport environment and immigration and customs services. For KLIA II, there are three of seven quality dimensions that have a significant positive effect on service evaluation, including airport service quality and facilities, service personnel and airport security and 
immigration and customs services. Then, the result of simultan hypothesis test both of SHIA and KLIA II, the seven dimensions of airport quality have a significant positive effect on service evaluation of airport services.

\section{Keywords : Service Quality, Perception, Customer Satisfaction}

\section{PENDAHULUAN}

Seiring berkembangnya zaman yang ditandai perkembangan teknologi dan informasi semakin mempermudah manusia dalam proses pemenuhan kebutuhan hidupnya, baik kebutuhan primer, sekunder maupun tersier. Salah satunya kebutuhan dalam moda transportasi, dampak dari perkembangan teknologi khususnya dalam bidang transportasi mampu meningkatkan tingkat mobilitas perpindahan manusia maupun barang dari satu tempat ke tempat lain yang semakin tinggi. Mobilitas perpindahan yang semakin tinggi menyebabkan kebutuhan akan sarana transportasi juga semakin besar, maka diperlukan jasa yang dapat memenuhi kebutuhan mobilisasi tersebut (Maulana, 2017). Sehingga banyak perusahaan jasa yang menawarkan jasanya untuk memenuhi kebutuhan mobilisasi. Diikuti dengan perkembangan terknologi membuat manusia menginginkan kebutuhannya terpenuhi dengan cepat dan mudah. Salah satu akses untuk melakukan mobilitas dengan mudah dan cepat dari satu tempat ke tempat lain yang cukup jauh yaitu menggunakan moda transportasi udara (Maulana, 2017). Dari segi biaya konsumen harus mengeluarkan biaya yang relatif lebih besar dibanding moda transportasi lainnya, namun bagi orang yang mengutamakan kecepatan dan ketepatan waktu dalam melakukan perjalanan pengeluaran biaya tersebut tidak menjadi persoalan selama kualitas layanan yang diberikan dapat memuaskan pengguna jasa.

$$
\text { Dalam melakukan perjalanan }
$$
menggunakan moda transportasi udara dalam hal ini (pesawat terbang), sangat erat kaitannya dengan bandara yang digunakan sebagai tempat lepas landas atau mendarat pesawat tersebut. Berdasarkan Peraturan Pemerintah Republik Indonesia Nomor 70 tahun 2001 tentang Kebandarudaraan "Bandara adalah lapangan terbang yang dipergunakan untuk mendarat dan lepas landas pesawat udara, dan naik turunnya penumpang atau bongkar muatan kargo atau pos yang dilengkapi dengan fasilitas keselamatan penerbangan ". Menurut Dewan Bandara Internasional/Airport Council
International (ACI) bandara tersibuk di Indonesia yaitu Bandara Internasional Soekarno-Hatta (Cengkareng) yang terletak di Jakarta sebagai ibukota Negara Kesatuan Republik Indonesia (NKRI) yang bertindak sebagai salah satu pintu bagi penerbangan domestik maupun internasional. Sedangkan bandara tersibuk di Malaysia yaitu Kuala Lumpur International Airport 2 (KLIA 2) yang terletak di Sepang Negara bagian Selangor. Bandara ini melayani berbagai macam penerbangan baik penerbangan domestik mupun Internasional.

Berdasarkan data yang diperoleh dari Dewan Bandara Internasional/Airport Council International(https://aci.aero/news/2019/03/13/ preliminary-world-airport-traffic-rangkingsreleased/) tentang peringkat bandara tersibuk di dunia tahun 2018, menunjukan bahwa Bandara Soekarno-Hatta International Airport (SHIA) masuk ke dalam top 20 kategori bandara tersibuk di dunia yaitu peringkat ke-18 dengan jumlah penumpang sebanyak 66.908.159 penumpang. Skytrax setiap tahunnya selalu melakukan riset mengenai kepuasan pelanggan, skytrax merupakan perusahaan yang melakukan riset mengenai pelayanan yang diberikan maskapai dan bandara serta membuat peringkat dari hasil riset tersebut. Berdasarkan hasil riset Skytrax dalam kategori World's Top 100 Airports2018(https://www.worldairportawards. com/worlds-top-100-airports-2018/). Soekarno Hatta Internasional Airport (SHIA) berada di peringkat 45 turun 1 peringkat dari tahun 2017 sedangkan Kuala Lumpur International Airport 2 (KLIA 2) berada di peringkat 44 turun 10 peringkat dari tahun 2017. Penurunan peringkat ini harus menjadi evaluasi manajemen kedua bandara tersebut, mengingat kedua bandara tersebut merupakan bandara tersibuk di masingmasing negara terutama Soekarno Hatta Internasional Airport (SHIA) yang berada di peringkat 18 bandara tersibuk di dunia seharusnya mampu memberikan pelayanan yang lebih baik lagi mengingat banyaknya jumlah penumpang yang menggunakan jasanya. Adanya riset atau survey yang dilakukan Skytrax tiap tahunnya menandakan bahwa kualitas pelayanan merupakan hal penting yang 
perlu diperhatikan oleh setiap bandara hal ini karena bandara merupakan perusahaan yang bergerak di bidang jasa, sehingga kepuasan dari pelanggan sangatlah penting (Ida, Vicenta dan Lilian, 2015).

Perubahan sistem nilai yang terjadi di masyarakat atas pelayanan jasa penerbangan saat ini ditandai dengan fenomena bahwa pengguna jasa penerbangan tidak hanya menginginkan sekedar sampai tempat tujuan, namun juga menginginkan pelayanan dan pengalaman di bandara yang memuaskan dari mulai datang di terminal bandara sampai dengan menunggu pemberangkatan pesawat terbang. Untuk menjalankan fungsinya dengan baik bandara harus dikelola secara terpadu sehingga pelayanan terhadap konsumen dapat diberikan dengan baik. Tata penyelenggaraan bandara harus sesuai dengan Keputusan Menteri Perhubungan No. 48 tahun 2002 tentang Penyelenggaraan Bandara Umum agar terwujudnya penyelenggaraan operasi penerbangan yang handal dan berkemapuan tinggi sesuai standar yang diberikan oleh Badan Standarisasi Indonesia (SNI) dan International Civil Aviation Organization (ICAO). Penumpang sebagai konsumen seharusnya merasa puas atas pelayanan yang diterimanya dari sejak datang hingga menunggu waktu pemberangkatan pesawat yang akan ditumpanginya. Faktor-faktor yang mempengaruhi calon penumpang dalam menentukan pilihan moda transportasi udara diantaranya : biaya, kinerja, petugas bandara, pengalaman, fasilitas bandara, lokasi, reputasi dan kualitas pelayanan Pudjo (2009).

Perubahan sistem nilai juga terjadi di bandara, bandara tidak hanya berfokus pada bisnis penerbangan (aeronautika) saja namun berfokus juga pada bisnis non-penerbangan (non-aeronautika). Alasan utama mengapa banyak bandara lebih fokus dalam bisnis non penerbangan terutama karena dalam sebuah studi yang dilakukan oleh JD Power and Associates, dimana "Penumpang yang senang adalah pemboros yang super" studi ini mengemukakan bahwa ketika penumpang mencapai tingkat kepuasan tertinggi ketika menggunakan jasa bandara, pengeluaran ritel bandara juga akan meningkat $45 \%$. Hal ini akan menjadi dampak besar bagi bisnis bandara karena banyak bandara di seluruh dunia telah mengalihkan fokus mereka lebih ke pendapatan non-aeronautika.
Kualitas pelayanan tidak dapat dinilai berdasarkan sudut pandang perusahaan melainkan harus dipandang dari sudut pandang penilaian pelanggan. Tjiptono dan Chandra (2005) menyatakan "kualitas pelayanan sebagai ukuran seberapa baik tingkat layanan yang diberikan penyedia layanan mampu memenuhi harapan pelanggan". Penilaian yang berasal dari persepsi pelanggan sangat dibutuhkan untuk menilai sejauh mana kualitas pelayanan suatu bandara secara keseluruhan dan kesesuaian pelayanan yang diterima dengan ekspektasi awal pelanggan terhadap bandara. Mengukur kepuasan pelanggan dalam hal ini (penumpang) sangat bermanfaat bagi perusahaan untuk mengevaluasi bagian mana yang sudah baik dan bagian mana yang membutuhkan peningkatan Dhio dan Kasyful (2012). Umpan balik atau keluhan dari pelanggan dapat digunakan sebagai alat untuk mengukur kepuasan pelanggan Rangkuti (2003).

Salah satu cara untuk menilai atau mengukur kualitas pelayanan bandara yaitu dengan melakukan penilaian terhadap 7 dimensi kualitas bandara seperti yang dilakukan oleh Redha (2013) ketujuh dimensi tersebut diantaranya; akses bandara, layanan dan fasilitas bandara, fasilitas restoran atau tempat makan di bandara, fasilitas belanja bandara, personil layanan dan keamanan bandara, lingkungan bandara dan layanan imigrasi serta bea cukai. Kualitas pelayanan yang diberikan oleh pihak bandara terhadap konsumen sangatlah penting. Seperti yang diuraikan dalam Tjiptono (2005:121) menyatakan ada dua faktor utama yang mempengaruhi kualitas pelayanan yaitu pelayanan yang diharapkan (expected service) dan pelayanan yang dipersepsikan (perceived service). Jika pelayanan yang dipersepsikan sesuai dengan pelayanan yang diharapkan maka kualitas pelayanan tersebut akan dipersepsikan baik/positif sehingga konsumen akan puas begitu pula sebaliknya, jika pelayanan yang dipersepsikan tidak sesuai dengan pelayanan yang diharapkan maka kualitas pelayanan tersebut akan dipersepsikan buruk/negatif dan konsumen tidak akan puas. Oleh karena itu baik buruknya kualitas pelayanan tergantung pada kemampuan penyedia layanan dalam memenuhi harapan konsumennya. Apabila konsumen merasa puas, maka mereka akan kembali menggunakan pelayanan/jasa tersebut. namun, apabila konsumen tidak merasa puas maka konsumen 
akan mencari jasa lainnya dan beberapa akan menyebarkan citra buruk terhadap perusahaan sehingga dapat berakibat pada kerugian. Oleh karena itu kualitas pelayanan memiliki hubungan erat dengan kepuasan konsumen.

Penelitian yang dilakukan oleh Redha (2013) menyatakan bahwa dari 7 dimensi kualitas bandara terdapat 4 dimensi yang mempengaruhi persepsi pelanggan diantaranya akses bandara, fasilitas restoran atau tempat makan di bandara, lingkungan bandara dan layanan imigrasi serta bea cukai sedangkan dimensi yang tidak mempengaruhi persepsi pelanggan yaitu layanan dan fasilitas bandara, fasilitas belanja bandara, personil layanan dan keamanan bandara. Dalam agenda tahunan STIE Sutaatmadja terdapat suatu program akademik yaitu Kuliah Kerja Lapangan (KKL) ke luar negeri, untuk tahun 2019 program KKL akan diselenggarakan di Malaysia. Kegiatan ini bertujuan untuk meningkatkan pengetahuan khususnya di Bidang Akuntansi dan Manajemen dengan cara melakukan penelitian ke beberapa objek yang akan dikunjungi. Karena program KKL ini bersifat lintas negara maka mahasiswa akan melalui 2 Bandara yaitu Soekarno Hatta Internasional Airport (SHIA) dan Kuala Lumpur International Airport 2 (KLIA 2). Dalam penelitian ini Mahasiswa STIE Sutaatmadja menjadi objek penelitian yang bertindak sebagai pengguna jasa bandara. Peneliti ingin mengetahui persepsi Mahasiswa STIE Sutaatmadja sebagai pelanggan, dalam menilai kualitas pelayanan Soekarno Hatta Internasional Airport (SHIA) dan Kuala Lumpur International Airport 2 (KLIA 2) yang dinilai berdasarkan 7 dimensi kualitas diantaranya ; akses bandara, layanan dan fasilitas bandara, fasilitas restoran atau tempat makan di bandara , fasilitas belanja bandara, personil layanan dan keamanan bandara, lingkungan bandara dan layanan imigrasi serta bea cukai kemudian menilai di antara kedua bandara tersebut mana yang memiliki kualitas lebih baik menurut persepsi mahasiswa STIE Sutaatmadja.

Berdasarkan hal tersebut peneliti tertarik untuk meneliti lebih jauh mengenai persepsi mahasiswa STIE Sutaatmadja dalam menilai dimensi kualitas pelayanan di SHIA dan KLIA 2 , kemudian mencari tahu hubungannya dengan penilaian mahasiswa STIE Sutaatmadja terhadap kualitas bandara secara keseluruhan. Dengan judul penelitian "Persepsi Mahasiswa Terhadap Dimensi Kualitas Pelayanan Bandara
(Studi Kasus pada Soekarno Hatta Internasional Airport (SHIA) dan Kuala Lumpur International Airport 2 (KLIA 2)).

\section{HIPOTESIS}

H1 : Kualitas Akses Bandara berpengaruh positif terhadap evaluasi pelayanan keseluruhan H2 : Kualitas layanan dan fasilitas bandara berpengaruh positif terhadap evaluasi pelayanan keseluruhan

H3 : Kualitas fasilitas restoran bandara berpengaruh positif terhadap evaluasi pelayanan keseluruhan

H4 : Kualitas fasilitas belanja bandara berpengaruh positif terhadap evaluasi pelayanan keseluruhan

H5 : Kualitas personil layanan dan keamanan bandara berpengaruh positif terhadap evaluasi pelayanan keseluruhan

H6 : Kualitas lingkungan bandara berpengaruh positif terhadap evaluasi pelayanan keseluruhan

H7 : Kualitas layanan imigrasi dan bea cukai bandara berpengaruh positif terhadap evaluasi pelayanan keseluruhan

H8 : Kualitas akses bandara, layanan dan fasilitas bandara, fasilitas restoran bandara, fasilitas belanja bandara, personil layanan dan keamanan bandara, lingkungan bandara, dan layanan imigrasi dan bea cukai bandara secara simultan berpengaruh positif terhadap evaluasi pelayanan keseluruhan

\section{METODE PENELITIAN}

Metode penelitian yang digunakan yaitu metode kuantitatif deskriptif dan rumusan masalah yang berbentuk asosiatif dengan hubungan kausal dimana penelitian ini bertujuan untuk mengetahui pengaruh tujuh dimensi kualitas pelayanan bandara terhadap evaluasi layanan keseluruhan. Populasi yang digunakan dalam penelitian ini yaitu mahasiswa STIE Sutaatmadja peserta KKL yang bertindak sebagai pengguna jasa layanan Soekarno Hatta Internasional Airport (SHIA) dan Kuala Lumpur International Airport 2 (KLIA 2) sebanyak 140 orang. Teknik pemilihan sampel yang digunakan adalah Sample Random Sampling yaitu pengambilan sampel secara acak tanpa memberhatikan strata yang ada pada populasi (Hidayat, 2017). Menurut Roscoe dalam Sugiyono (2011:90) menyatakan bahwa "Ukuran sampel yang layak dalam penelitian adalah antara 30 sampai dengan 500". Oleh karena itu dari populasi yang 
berjumlah 140 orang, peneliti mengambil sampel sebanyak 120 orang dari keseluruhan populasi, yang terdiri atas 51 responden mahasiswa program studi akuntansi dan 69 responden mahasiswa program studi manajemen. Teknik pengumpulan data yang digunakan yaitu menggunakan kuesioner dan pengukuran menggunakan skala likert. Teknik pengujian data menggunakan uji reliabilitas, uji validitas dan uji asumsi klasik. Teknik analisis data dalam penelitian ini menggunakan teknik regresi linear berganda dan uji hipotesis (uji t dan uji f) yang diolah menggunakan program SPSS (Statistical Package for Sosial Science) Versi 20.0.

\section{HASIL PENELITIAN DAN PEMBAHASAN}

\section{Hasil uji validitas dan reliabilitas}

Tabel 1

Hasil uji validitas SHIA dan KLIA 2

\begin{tabular}{|c|c|c|c|c|c|c|}
\hline & Variabel & $\begin{array}{c}\text { Jenis } \\
\text { Variabel }\end{array}$ & $\begin{array}{l}\text { r-hitung } \\
\text { SHIA }\end{array}$ & $\begin{array}{l}\text { r-hitung } \\
\text { KLIA } 2\end{array}$ & r-tabel & Kesimpulan \\
\hline & X1 (Akses Bandara) & $\begin{array}{l}X 1.1 \\
X 1.2 \\
X 1.3 \\
\text { X1.4 }\end{array}$ & $\begin{array}{l}0,604 \\
0,560 \\
0,651 \\
0,633\end{array}$ & $\begin{array}{l}0,578 \\
0,416 \\
0,610 \\
0,617\end{array}$ & $\begin{array}{l}0,179 \\
0,179 \\
0,179 \\
0,179\end{array}$ & $\begin{array}{l}\text { Valid } \\
\text { Valid } \\
\text { Valid } \\
\text { Valid }\end{array}$ \\
\hline & $\begin{array}{l}\text { X2 (Layanan dan Fasilitas } \\
\text { Bandara) }\end{array}$ & $\begin{array}{l}\text { X2.1 } \\
\text { X2.2 } \\
\text { X2.3 } \\
\text { X2.4 }\end{array}$ & $\begin{array}{l}0,506 \\
0,309 \\
0.539 \\
0,424\end{array}$ & $\begin{array}{l}0,607 \\
0,383 \\
0.586 \\
0,327\end{array}$ & $\begin{array}{l}0,179 \\
0,179 \\
0,179 \\
0,179\end{array}$ & $\begin{array}{l}\text { Valid } \\
\text { Valid } \\
\text { Valid } \\
\text { Valid }\end{array}$ \\
\hline 苞 & X3 (Fasilitas Restoran Bandara) & $\begin{array}{l}\text { X3.1 } \\
\text { X3.2 } \\
\text { X3.3 } \\
\text { X3.4 }\end{array}$ & $\begin{array}{l}0,689 \\
0,721 \\
0,738 \\
0,635\end{array}$ & $\begin{array}{l}0,841 \\
0,840 \\
0,811 \\
0,804\end{array}$ & $\begin{array}{l}0,179 \\
0,179 \\
0,179 \\
0,179\end{array}$ & $\begin{array}{l}\text { Valid } \\
\text { Valid } \\
\text { Valid } \\
\text { Valid }\end{array}$ \\
\hline $\bar{\Xi}$ & X4 (Fasilitas Belanja Bandara) & $\begin{array}{l}\mathrm{X} 4.1 \\
\mathrm{X} 4.2 \\
\end{array}$ & $\begin{array}{l}0,412 \\
0,412 \\
\end{array}$ & $\begin{array}{l}0,247 \\
0,247 \\
\end{array}$ & $\begin{array}{l}0,179 \\
0,179 \\
\end{array}$ & $\begin{array}{l}\text { Valid } \\
\text { Valid } \\
\end{array}$ \\
\hline$\ddot{\theta}$ & $\begin{array}{l}\text { X5 (Personil layanan dan } \\
\text { Keamanan Bandara) }\end{array}$ & $\begin{array}{l}\text { X5.1 } \\
\text { X5.2 } \\
\text { X5.3 }\end{array}$ & $\begin{array}{l}0,607 \\
0,587 \\
0,700\end{array}$ & $\begin{array}{l}0,637 \\
0,728 \\
0,700\end{array}$ & $\begin{array}{l}0,179 \\
0,179 \\
0,179\end{array}$ & $\begin{array}{l}\text { Valid } \\
\text { Valid } \\
\text { Valid }\end{array}$ \\
\hline & X6 (Lingkungan Bandara) & $\begin{array}{l}\mathrm{X6.1} \\
\mathbf{X 6 . 2} \\
\text { X6.3 }\end{array}$ & $\begin{array}{l}0,731 \\
0,764 \\
0,711\end{array}$ & $\begin{array}{l}0,840 \\
0,843 \\
0,813\end{array}$ & $\begin{array}{l}0,179 \\
0,179 \\
0,179\end{array}$ & $\begin{array}{l}\text { Valid } \\
\text { Valid } \\
\text { Valid }\end{array}$ \\
\hline & $\begin{array}{l}\text { X7 (Layanan Imigrasi dan Bea } \\
\text { Cukai) }\end{array}$ & $\begin{array}{l}\mathrm{X} 7.1 \\
\mathrm{X} 7.2\end{array}$ & $\begin{array}{l}0,837 \\
0,837\end{array}$ & $\begin{array}{l}0,642 \\
0,642\end{array}$ & $\begin{array}{l}0,179 \\
0,179\end{array}$ & $\begin{array}{l}\text { Valid } \\
\text { Valid }\end{array}$ \\
\hline & luasi Layanan Keseluruhan (Y) & $\begin{array}{l}\text { Y.1 } \\
\text { Y.2 } \\
\text { Y.3 }\end{array}$ & $\begin{array}{l}0,745 \\
0,641 \\
0,685\end{array}$ & $\begin{array}{l}0,827 \\
0,801 \\
0,679\end{array}$ & $\begin{array}{l}0,179 \\
0,179 \\
0,179\end{array}$ & $\begin{array}{l}\text { Valid } \\
\text { Valid } \\
\text { Valid }\end{array}$ \\
\hline
\end{tabular}

Sumber : output SPSS 20.0, data primer yang diolah (2019)

Tabel 1 menunjukan hasil uji validitas, dengan jumlah responden sebanyak 120 maka nilai $r$ tabel dengan nilai signifikansi $5 \%$ adalah 0,179 . Hasil perhitungan uji validitas menunjukan bahwa setiap item pertanyaan baik untuk SHIA maupun KLIA memiliki $\mathrm{r}$ hitung $>\mathrm{r}$ tabel pada nilai signifikansi $5 \%$. Oleh karena itu dapat disimpulkan bahwa seluruh item pertanyaan dalam kuesioner penelitian ini valid sehingga dapat digunakan sebagai instrumen penelitian.

Sebuah kuesioner atau instrumen penelitian selain valid juga harus reliabel. Menurut Sugiyono (2011:48) Suatu variabel dinyatakan reliabel apabila memberikan nilai Cronbach Alpha $(\alpha)>0,60$. Berikut ini hasil uji reliabel untuk SHIA dan KLIA 2: 
Tabel 2

Hasil uji reliabilitas SHIA dan KLIA 2

\begin{tabular}{ccccc}
\hline Variabel & $\begin{array}{c}\text { alpha } \\
\text { cronbach } \\
\text { SHIA }\end{array}$ & $\begin{array}{c}\text { alpha } \\
\text { cronbach } \\
\text { KLIA 2 }\end{array}$ & alpha & Kesimpulan \\
\hline X1 & 0,801 & 0,770 & 0,6 & Reliabel \\
X2 & 0,678 & 0,678 & 0,6 & Reliabel \\
X3 & 0,854 & 0,924 & 0,6 & Reliabel \\
X4 & 0,684 & 0,696 & 0,6 & Reliabel \\
X5 & 0,790 & 0,830 & 0,6 & Reliabel \\
X6 & 0,860 & 0,917 & 0,6 & Reliabel \\
X7 & 0,911 & 0,782 & 0,6 & Reliabel \\
Y & 0,832 & 0,880 & 0,6 & Reliabel \\
\hline \multicolumn{5}{l}{ Sumber : output SPSS 20.0, data primer yang diolah (2019) }
\end{tabular}

Tabel 2 menunjukan hasil uji reliabilitas, nilai koefisien reliabilitas kuesioner SHIA memiliki nilai Cronbach Alfa variabel X1 sebesar 0,801, X2 sebesar 0,678, X3 sebesar 0,854, X4 sebesar 0,684, X5 sebesar 0,790, X6 sebesar 0,860, X7 sebesar 0,911 dan Y sebesar 0,832. Sedangkan nilai koefisien reliabilitas kuesioner KLIA 2 memiliki nilai Cronbach Alfa variabel X1 sebesar 0,770, X2 sebesar 0,678, X3 sebesar 0,924, X4 sebesar 0,696, X5 sebesar 0,830, X6 sebesar 0,917, X7 sebesar 0,782 dan Y sebesar 0,880. Karena nilai alpha cronbach seluruh variabel baik SHIA maupun KLIA 2 lebih besar dari 0,60 maka dapat disimpulkan bahwa semua variabel dalam penelitian ini baik untuk SHIA maupun KLIA 2 dapat dinyatakan reliabel atau konsisten sehingga dapat digunakan sebagai instrumen penelitian.

\section{Hasil Uji Asumsi Klasik}

a. Hasil Uji Normalitas

Menurut Ghozali (2005:110) "Uji normalitas bertujuan untuk menguji data model regresi berdistribusi normal atau tidak". Untuk mengetahui normalitas data, dilihat berdasarkan diagram Normal P-P Plot of Standardized Residuals. Dalam memeriksa asumsi normalitas melalui plot P-P, residu dari populasi normal harus mendekati garis lurus untuk memenuhi anggapan normalitas dan grafik histogramnya menunjukan pola distribusi normal maka model regresi memenuhi asumsi normalitas.

1) Hasil Uji Normalitas $S H I A$

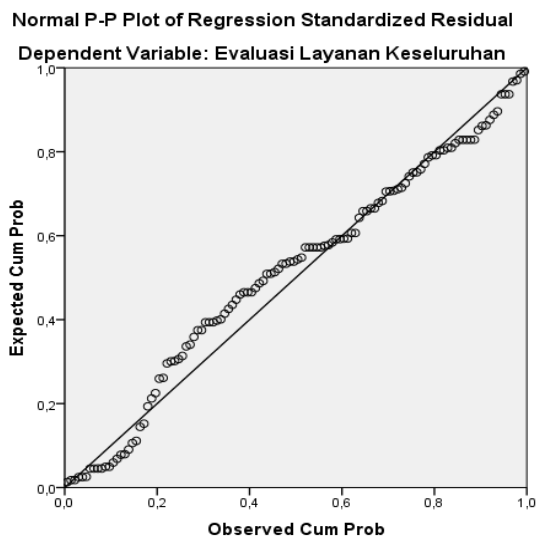

Gambar 1

Grafik normal Plot P-P hasil uji normalitas SHIA

Sumber : output SPSS 20.0, data primer yang diolah (2019) 
Gambar 1 menunjukan bahwa data menyebar disekitar garis diagonal/normal dan mengikuti arah garis diagonal/normal maka dapat disimpulkan model regresi SHIA memenuhi asumsi normalitas.

2) Hasil Uji Normalitas KLIA 2

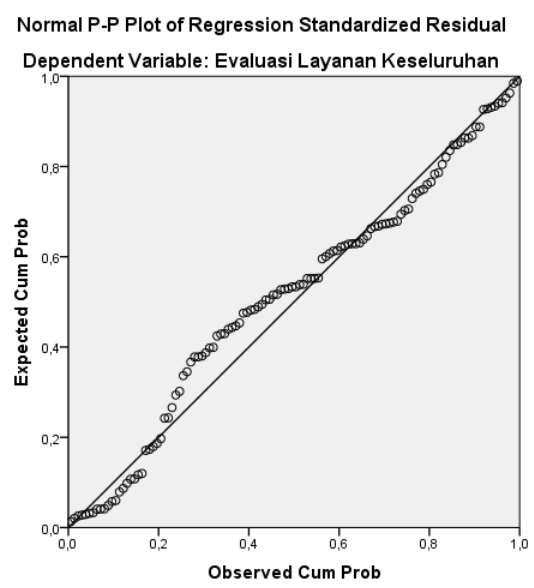

Gambar 2

Grafik normal Plot P-P hasil uji normalitas KLIA 2

Sumber : output SPSS 20.0, data primer yang diolah (2019)

Gambar 2 menunjukan bahwa data menyebar disekitar garis diagonal/normal dan mengikuti arah garis diagonal/normal maka dapat disimpulkan model regresi KLIA 2 memenuhi asumsi normalitas.

b. Hasil Uji Multikolinearitas

Menurut Ghozali (2005 : 91) "Uji multikoloneritas bertujuan untuk menguji apakah dalam model regresi ditemukan adanya korelasi antara variabel bebas (independen)". Multikolinearitas terjadi apabila nilai VIF (Varian Inflation Factor) > 10; dan jika tolerance < 0,1. Berikut ini hasil uji multikolinearitas untuk SHIA dan KLIA 2:

1) Hasil Uji Multikolinearitas SHIA

Tabel 3

Hasil Uji Multikolinearitas SHIA

\begin{tabular}{lll}
\hline \multirow{2}{*}{ Model } & \multicolumn{2}{l}{ Collinearity Statistic } \\
\cline { 2 - 3 } & Tolerance & VIF \\
\hline Akses Bandara & 0,417 & 2,400 \\
Fasilitas dan Layanan Bandara & 0,445 & 2,249 \\
Fasilitas Restoran Bandara & 0,431 & 2,323 \\
Fasilitas Belanja Bandara & 0,521 & 1,918 \\
Personil Layanan dan Keamanan Bandara & 0,261 & 3,827 \\
Lingkungan Bandara & 0,552 & 1,812 \\
Layanan Imigrasi dan Bea Cukai Bandara & 0,305 & 3,283 \\
\hline
\end{tabular}

Sumber : output SPSS 20.0, data primer yang diolah (2019)

Tabel 3 menunjukan bahwa ketujuh variabel independen memiliki nilai tolerance untuk variabel akses bandara sebesar 0,417; variabel layanan dan fasilitas bandara menunjukan angka 0,445 ; variabel fasilitas restoran bandara menunjukan angka 0,431 ; variabel fasilitas belanja bandara menunjukan angka 0,521 ; variabel personil layanan dan keamanan bandara menunjukan angka 0,261; variabel lingkungan bandara menunjukan angka 0,552; dan variabel layanan imigrasi dan bea cukai menunjukan angka 0,305 . Karena nilai tolerance ketujuh variabel independen lebih besar dari 0,1 , maka dapat disimpulkan bahwa nilai tolerance ketujuh variabel independen bebas multikolinearitas. Kemudian untuk nilai VIF 
dari variabel akses bandara sebesar 2,400 ; variabel layanan dan fasilitas bandara menunjukan angka 2,249; variabel fasilitas restoran bandara menunjukan angka 2,323; variabel fasilitas belanja bandara menunjukan angka 1,918; variabel personil layanan dan keamanan bandara menunjukan angka 3,827; variabel lingkungan bandara menunjukan angka 1,812; dan variabel layanan imigrasi dan bea cukai menunjukan angka 3,283. Karena nilai VIF ketujuh variabel independen kurang dari 10, maka dapat disimpulkan bahwa nilai VIF ketujuh variabel independen bebas multikolinearitas. Dari angka-angka tersebut dapat disimpulkan bahwa model regresi penelitian SHIA bebas dari masalah multikolinearitas.

2) Hasil Uji Multikolinearitas KLIA 2

Tabel 4

Hasil Uji Multikolinearitas KLIA 2

\begin{tabular}{lll}
\hline \multirow{2}{*}{ Model } & \multicolumn{2}{l}{ Collinearity Statistic } \\
\cline { 2 - 3 } & Tolerance & VIF \\
\hline Akses Bandara & 0,393 & 2,544 \\
Fasilitas dan Layanan Bandara & 0,332 & 3,013 \\
Fasilitas Restoran Bandara & 0,340 & 2,944 \\
Fasilitas Belanja Bandara & 0,404 & 2,472 \\
Personil Layanan dan Keamanan Bandara & 0,358 & 2,796 \\
Lingkungan Bandara & 0,518 & 1,932 \\
Layanan Imigrasi dan Bea Cukai Bandara & 0,415 & 2,410 \\
\hline
\end{tabular}

Sumber : output SPSS 20.0, data primer yang diolah (2019)

Tabel 4 menunjukan bahwa ketujuh variabel independen memiliki nilai tolerance dari variabel akses bandara sebesar 0,393; variabel layanan dan fasilitas bandara menunjukan angka 0,332; variabel fasilitas restoran bandara menunjukan angka 0,340; variabel fasilitas belanja bandara menunjukan angka 0,404; variabel personil layanan dan keamanan bandara menunjukan angka 0,358; variabel lingkungan bandara menunjukan angka 0,518; dan variabel layanan imigrasi dan bea cukai menunjukan angka 0,415 . Karena nilai tolerance ketujuh variabel independen lebih besar dari 0,1 , maka dapat disimpulkan bahwa nilai tolerance ketujuh variabel independen bebas multikolinearitas. Sedangkan nilai VIF dari variabel akses bandara sebesar 2,544; variabel layanan dan fasilitas bandara menunjukan angka 3,013; variabel fasilitas restoran bandara menunjukan angka 2,944; variabel fasilitas belanja bandara menunjukan angka 2,472; variabel personil layanan dan keamanan bandara menunjukan angka 2,796; variabel lingkungan bandara menunjukan angka 1,932; dan variabel layanan imigrasi dan bea cukai menunjukan angka 2,410. Karena nilai VIF ketujuh variabel independen kurang dari 10, maka dapat disimpulkan bahwa nilai VIF ketujuh variabel independen bebas multikolinearitas. Dari angka-angka tersebut dapat disimpulkan bahwa model regresi penelitian KLIA 2 bebas dari masalah multikolinearitas.

c. Hasil Uji Heteroskedastisitas

Menurut Ghozali (2005:105) "Uji heteroskedastisitas bertujuan untuk mengetahui apakah dalam model regresi terjadi perbedaan variance dari residual pengamatan yang satu ke pengamatan lain dalam suatu model regresi". Ketentuan uji heteroskedastisitas yaitu :

1. Jika ada pola tertentu, seperti titik-titik yang ada membentuk pola tertentu yang teratur (bergelombang, melebar kemudian menyempit), maka mengindikasikan telah terjadi heteroskedastisitas.

2. Jika tidak ada pola yang jelas, serta titik-titik menyebar diatas dan dibawah angka 0 pada sumbu Y, maka tidak terjadi heteroskedastisitas. 
1) Hasil uji heteroskedastisitas SHIA

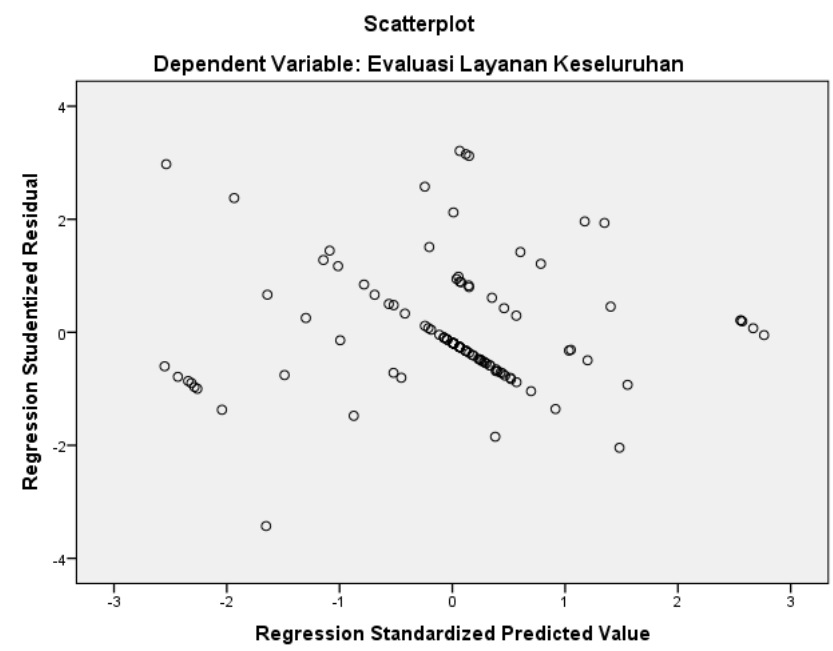

Gambar 3

Scatterplot uji heteroskedastisitas

Sumber : output SPSS 20.0, data primer yang diolah (2019)

Berdasarkan gambar 3 terlihat bahwa titik-titik data menyebar secara acak baik diatas maupun dibawah angka nol pada sumbu y dan tidak membentuk suatu pola tertentu. Sehingga dapat disimpulkan bahwa tidak terjadi heteroskedastisitas pada model regresi SHIA.

2) Hasil Uji Heteros Kedastisitas KLIA 2

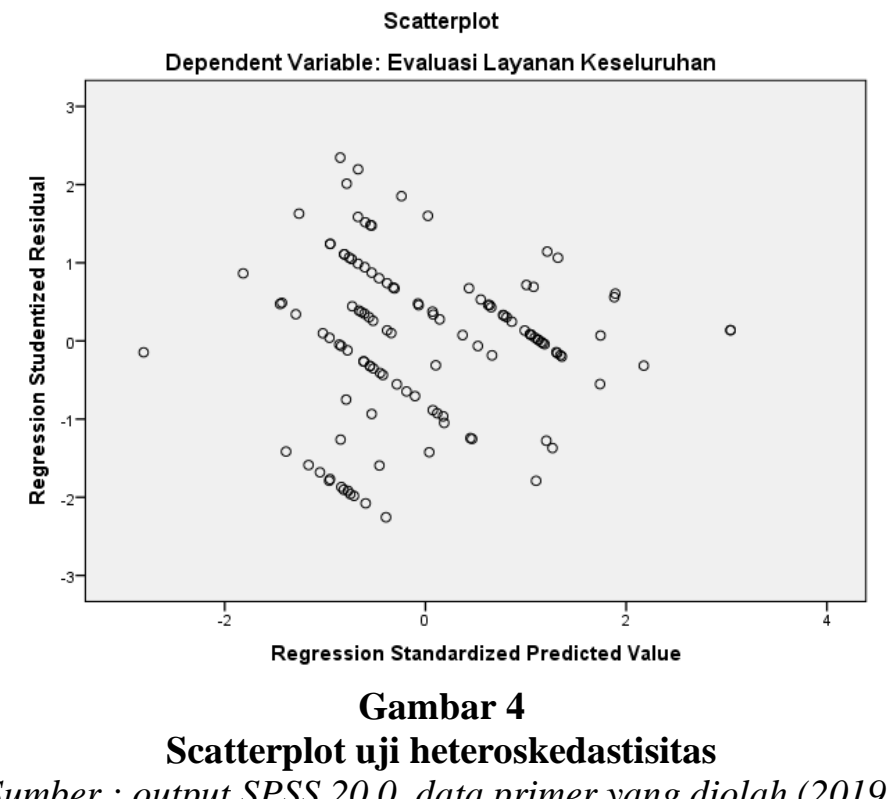

Sumber : output SPSS 20.0, data primer yang diolah (2019)

Berdasarkan gambar 4 terlihat bahwa titik-titik data menyebar secara acak baik diatas maupun dibawah angka nol pada sumbu y dan tidak membentuk suatu pola tertentu. Sehingga dapat disimpulkan bahwa tidak terjadi heteroskedastisitas pada model regresi KLIA 2. 


\section{Analisis Statistik Deskriptif}

Statistik deskriptif memberikan penjelasan mengenai nilai rata-rata (mean) dan nilai standar deviasi variabel independen dan variabel dependen. Berikut ini hasil analisis statistik SHIA dan KLIA 2 :

Tabel 5

Hasil Statistik Deskriptif

\begin{tabular}{lrrrr}
\hline \multirow{2}{*}{ Variabel } & \multicolumn{2}{c}{ SHIA } & \multicolumn{2}{c}{ KLIA 2 } \\
\cline { 2 - 5 } \multicolumn{1}{c}{ Mean } & Std. Deviasi & \multicolumn{1}{c}{ Mean } & Std. Deviasi \\
\hline Evaluasi Layanan Keseluruhan & $\mathbf{1 2 , 1 5 8}$ & $\mathbf{1 , 3 4 0}$ & $\mathbf{1 0 , 3 3 3}$ & $\mathbf{2 , 1 9 7}$ \\
Akses Bandara & 16,150 & 1,643 & 14,533 & 2,400 \\
Fasilitas dan Layanan Bandara & 15,250 & 1,843 & 12,983 & 2,579 \\
Fasilitas Restoran Bandara & 16,000 & 1,887 & 15,841 & 2,219 \\
Fasilitas Belanja Bandara & 7,766 & 1,128 & 7,808 &, 972 \\
Personil Layanan dan Keamanan Bandara & 11,600 & 1,721 & 9,000 & 2,634 \\
Lingkungan Bandara & 12,316 & 1,483 & 12,066 & 1,708 \\
Layanan Imigrasi dan Bea Cukai & 7,566 & 1,418 & 5,966 & 1,714 \\
\hline
\end{tabular}

Sumber : output SPSS 20.0, data primer yang diolah (2019)

Berdasarkan tabel 5 menunjukan untuk 7 dimensi kualitas pelayanan bandara, Soekarno Hatta International Airport (SHIA) memiliki nilai mean lebih tinggi dibanding Kuala Lumpur International Airport 2 (KLIA 2) untuk variabel; akses bandara sebesar 16,150 dengan standar deviasi sebesar 1,643, variabel fasilitas dan layanan bandara sebesar 15,250 dengan standar deviasi sebesar 1,843, variabel fasilitas restoran bandara sebesar 16,000 dengan standar deviasi sebesar 1,887; variabel personil layanan dan keamanan bandara sebesar 11,600 dengan standar deviasi sebesar 1,721; variabel lingkungan bandara sebesar 12,316 dengan standar deviasi sebesar 1,483 dan variabel layanan imigrasi dan bea cukai sebesar 7,566 dengan standar deviasi 1,418. Sedangkan Kuala Lumpur International Airport 2 (KLIA 2) unggul dalam variabel fasilitas belanja bandara dengan nilai mean sebesar 7,808 dan standar deviasi sebesar 0,972. Kemudian untuk variabel evaluasi pelayanan keseluruhan Soekarno Hatta International Airport (SHIA) unggul dengan nilai mean sebesar 12,1583 dan standar deviasi sebesar 1,34099.

\section{Analisis Regresi Linear Berganda}

Dalam penelitian ini uji hipotesis menggunakan regresi berganda dimana akan diuji secara empirik untuk mencari hubungan fungsional dua atau lebih variabel bebas dengan variabel terikat. Hasil uji regresi linier berganda SHIA dan KLIA 2 sebagai berikut :

a. Analisis regresi linear berganda SHIA

Tabel 6

Hasil Regresi Linear Berganda SHIA

\begin{tabular}{|c|c|c|c|}
\hline \multirow[t]{2}{*}{ Model } & \multicolumn{2}{|c|}{$\begin{array}{l}\text { Unstandarized } \\
\text { Coefficients }\end{array}$} & \multirow{2}{*}{$\begin{array}{c}\begin{array}{r}\text { Standarized } \\
\text { Coefficients }\end{array} \\
\text { Beta } \\
\end{array}$} \\
\hline & B & Std. Error & \\
\hline$\overline{\text { (constant) }}$ & 1,544 & 0,881 & \\
\hline Akses Bandara (X1) & 0,247 & 0,075 & 0,302 \\
\hline Fasilitas dan Layanan Bandara (X2) & 0,058 & 0,065 & 0,079 \\
\hline Fasilitas Restoran Bandara (X3) & 0,057 & 0,064 & 0,081 \\
\hline Fasilitas Belanja Bandara (X4) & 0,087 & 0,098 & 0,073 \\
\hline Personil Layanan dan Keamanan Bandara (X5) & 0,072 & 0,090 & 0,092 \\
\hline Lingkungan Bandara (X6) & 0,281 & 0,072 & 0,311 \\
\hline Layanan Imigrasi dan Bea Cukai Bandara (X7) & 0,394 & 0,102 & 0,416 \\
\hline Dependent Variabel : Evaluasi Layanan Keseluruhan & & & \\
\hline
\end{tabular}

Sumber : output SPSS 20.0, data primer yang diolah (2019) 
Berdasarkan hasil uji regresi linier pada tabel 6 dikembangkan dengan model persamaan regresi linier berganda sebagai berikut :

$\mathrm{Y}=1,544+0,247 \mathrm{X} 1+0,058 \mathrm{X} 2+0,057 \mathrm{X} 3+$ $0,087 \mathrm{X} 4+0,072 \mathrm{X} 5+0,281 \mathrm{X} 6+0,394 \mathrm{X} 7+$ 0,881

Persamaan regresi linier berganda dapat dijelaskan sebagai berikut :

1) Konstanta sebesar 1,544 artinya jika variabel Akses Bandara, Fasilitas dan Layanan Bandara, Fasilitas Restoran Bandara, Fasilitas Belanja Bandara, Personil Layanan dan Keamanan Bandara, Lingkungan Bandara, Layanan Imigrasi dan Bea Cukai ditiadakan maka Evaluasi Pelayanan Keseluruhan sebesar 1,544.

2) Koefisien regresi $X 1$ sebesar 0,247 artinya setiap kenaikan satu satuan Akses Bandara akan meningkatkan Evaluasi Pelayanan Keseluruhan sebesar 0,247. Dan sebaliknya, setiap penurunan satu satuan Akses Bandara akan menurunkan Evaluasi Pelayanan Keseluruhan sebesar 0,247 dengan anggapan bahwa X2, X3, X4, X5, X6, dan X7 tetap.

3) Koefisien regresi $X 2$ sebesar 0,058 artinya setiap kenaikan satu satuan Layanan dan Fasilitas Bandara akan meningkatkan Evaluasi Pelayanan Keseluruhan sebesar 0,058. Dan sebaliknya, setiap penurunan satu satuan Layanan dan Fasilitas Bandara akan menurunkan Evaluasi Pelayanan Keseluruhan sebesar 0,058 dengan anggapan bahwa X1, X3, X4, X5, X6, dan X7 tetap.

4) Koefisien regresi $X 3$ sebesar 0,057 artinya setiap kenaikan satu satuan Fasilitas Restoran Bandara akan meningkatkan Evaluasi Pelayanan Keseluruhan sebesar 0,057. Dan sebaliknya, setiap penurunan satu satuan Fasilitas Restoran Bandara akan menurunkan Evaluasi Pelayanan
Keseluruhan sebesar 0,057 dengan anggapan bahwa X1, X2, X4, X5, X6, dan X7 tetap.

5) Koefisien regresi $X 4$ sebesar 0,087 artinya setiap kenaikan satu satuan Fasilitas Belanja Bandara akan meningkatkan Evaluasi Pelayanan Keseluruhan sebesar 0,087. Dan sebaliknya, setiap penurunan satu satuan Fasilitas Belanja Bandara akan menurunkan Evaluasi Pelayanan Keseluruhan sebesar 0,087 dengan anggapan bahwa X1, X2, X3, X5, X6, dan X7 tetap.

6) Koefisien regresi $X 5$ sebesar 0,072 artinya setiap kenaikan satu satuan Personil Layanan dan Keamanan Bandara akan meningkatkan Evaluasi Pelayanan Keseluruhan sebesar 0,072. Dan sebaliknya, setiap penurunan satu satuan Personil Layanan dan Keamanan Bandara akan menurunkan Evaluasi Pelayanan Keseluruhan sebesar 0,072 dengan anggapan bahwa X1, X2, X3, X4, X6, dan X7 tetap.

7) Koefisien regresi $X 6$ sebesar 0,281 artinya setiap kenaikan satu satuan Lingkungan Bandara akan meningkatkan Evaluasi Pelayanan Keseluruhan sebesar 0,281. Dan sebaliknya, setiap penurunan satu satuan Lingkungan Bandara akan menurunkan Evaluasi Pelayanan Keseluruhan sebesar 0,281 dengan anggapan bahwa X1, X2, X3, X4, X5, dan X7 tetap.

8) Koefisien regresi $X 7$ sebesar 0,394 artinya setiap kenaikan satu satuan Layanan Imigrasi dan Bea Cukai akan meningkatkan Evaluasi Pelayanan Keseluruhan sebesar 0,394. Dan sebaliknya, setiap penurunan satu satuan Layanan Imigrasi dan Bea Cukai akan menurunkan Evaluasi Pelayanan Keseluruhan sebesar 0,394 dengan anggapan bahwa X1, X2, X3, X4, $\mathrm{X} 5$, dan X6 tetap. 
b. Analisis regresi linear berganda KLIA 2

Tabel 7

Hasil Regresi Linear Berganda KLIA 2

\begin{tabular}{lccc}
\hline \multirow{2}{*}{ Model } & \multicolumn{2}{c}{$\begin{array}{c}\text { Unstandarized } \\
\text { Coefficients }\end{array}$} & $\begin{array}{c}\text { Standarized } \\
\text { Coefficients }\end{array}$ \\
\cline { 2 - 4 } & B & Std. Error & Beta \\
\hline (constant) & 0,523 & 1,383 & \\
Akses Bandara (X1) & 0,047 & 0,103 & 0,052 \\
Fasilitas dan Layanan Bandara (X2) & 0,312 & 0,104 & 0,367 \\
Fasilitas Restoran Bandara (X3) & 0,070 & 0,120 & 0,070 \\
Fasilitas Belanja Bandara (X4) & 0,073 & 0,250 & 0,032 \\
Personil Layanan dan Keamanan Bandara (X5) & 0,254 & 0,098 & 0,264 \\
Lingkungan Bandara (X6) & 0,142 & 0,126 & 0,110 \\
Layanan Imigrasi dan Bea Cukai Bandara (X7) & 0,200 & 0,140 & 0,156 \\
Dependent Variabel : Evaluasi Layanan Keseluruhan & & & \\
\hline
\end{tabular}

Sumber : output SPSS 20.0, data primer yang diolah (2019)

Berdasarkan hasil uji regresi linier pada tabel 7 dapat dikembangkan dengan model persamaan regresi linier berganda sebagai berikut :

$\mathrm{Y}=0,523+0,047 \mathrm{X} 1+0,312 \mathrm{X} 2+0,070 \mathrm{X} 3+$ $0,073 \mathrm{X} 4+0,254 \mathrm{X} 5+0,142 \mathrm{X} 6+0,200 \mathrm{X} 7+$ 1,383

Persamaan regresi linier berganda dapat dijelaskan sebagai berikut :

1) Konstanta sebesar 0,523 artinya jika variabel Akses Bandara, Fasilitas dan Layanan Bandara, Fasilitas Restoran Bandara, Fasilitas Belanja Bandara, Personil Layanan dan Keamanan Bandara, Lingkungan Bandara, Layanan Imigrasi dan Bea Cukai ditiadakan maka Evaluasi Pelayanan Keseluruhan sebesar 0,523.

2) Koefisien regresi $X 1$ sebesar 0,047 artinya setiap kenaikan satu satuan Akses Bandara akan meningkatkan Evaluasi Pelayanan Keseluruhan sebesar 0,047. Dan sebaliknya, setiap penurunan satu satuan Akses Bandara akan menurunkan Evaluasi Pelayanan Keseluruhan sebesar 0,047 dengan anggapan bahwa X2, X3, X4, X5 , X6, dan X7 tetap.

3) Koefisien regresi $X 2$ sebesar 0,312 artinya setiap kenaikan satu satuan Layanan dan Fasilitas Bandara akan meningkatkan Evaluasi Pelayanan Keseluruhan sebesar 0,312. Dan sebaliknya, setiap penurunan satu satuan Layanan dan Fasilitas Bandara akan menurunkan Evaluasi Pelayanan Keseluruhan sebesar 0,312 dengan anggapan bahwa X1, X3, X4, X5, X6, dan X7 tetap.
4) Koefisien regresi $X 3$ sebesar 0,070 artinya setiap kenaikan satu satuan Fasilitas Restoran Bandara akan meningkatkan Evaluasi Pelayanan Keseluruhan sebesar 0,070. Dan sebaliknya, setiap penurunan satu satuan Fasilitas Restoran Bandara akan menurunkan Evaluasi Pelayanan Keseluruhan sebesar 0,070 dengan anggapan bahwa X1, X2, X4, X5, X6, dan X7 tetap.

5) Koefisien regresi $X 4$ sebesar 0,073 artinya setiap kenaikan satu satuan Fasilitas Belanja Bandara akan meningkatkan Evaluasi Pelayanan Keseluruhan sebesar 0,073. Dan sebaliknya, setiap penurunan satu satuan Fasilitas Belanja Bandara akan menurunkan Evaluasi Pelayanan Keseluruhan sebesar 0,073 dengan anggapan bahwa X1, X2, X3, X5, X6, dan X7 tetap.

6) Koefisien regresi $X 5$ sebesar 0,254 artinya setiap kenaikan satu satuan Personil Layanan dan Keamanan Bandara akan meningkatkan Evaluasi Pelayanan Keseluruhan sebesar 0,054. Dan sebaliknya, setiap penurunan satu satuan Personil Layanan dan Keamanan Bandara akan menurunkan Evaluasi Pelayanan Keseluruhan sebesar 0,054 dengan anggapan bahwa X1, X2, X3, X4, X6, dan X7 tetap.

7) Koefisien regresi $X 6$ sebesar 0,142 artinya setiap kenaikan satu satuan Lingkungan Bandara akan meningkatkan Evaluasi Pelayanan Keseluruhan sebesar 0,142. Dan sebaliknya, setiap penurunan satu satuan Lingkungan Bandara akan menurunkan 
Evaluasi Pelayanan Keseluruhan sebesar 0,142 dengan anggapan bahwa X1, X2, X3, $\mathrm{X} 4, \mathrm{X} 5$, dan X7 tetap.

8) Koefisien regresi $X 7$ sebesar 0,200 artinya setiap kenaikan satu satuan Layanan Imigrasi dan Bea Cukai akan meningkatkan Evaluasi Pelayanan Keseluruhan sebesar 0,200. Dan sebaliknya, setiap penurunan satu satuan Layanan Imigrasi dan Bea Cukai akan menurunkan Evaluasi Pelayanan Keseluruhan sebesar 0,200 dengan anggapan bahwa X1, X2, X3, X4, X5, dan X6 tetap.

\section{Hasil Uji secara parsial (uji t)}

Menurut Ghozali (2005:84) "Uji t pada menunjukan sebarapa jauh pengaruh suatu variabel independen secara individual terhadap variabel dependen". Pengujian ini dengan cara membandingkan nilai probabilitas atau $\mathrm{p}$-value atau niali signifikan $\mathrm{t}$ dengan taraf signifikansi 0,05 dan membandingkan antara t-hitung dan $\mathrm{t}$ tabel dengan tingkat signifikansi 5\% maka $\mathrm{t}$-tabel $=1,980$. Berikut ini hasil uji $\mathrm{t}$ untuk SHIA dan KLIA 2 :

Tabel 8

Hasil Uji t SHIA

\begin{tabular}{lcc}
\hline \multicolumn{1}{c}{ Model } & t & Sig. \\
\hline (constant) & 1,752 & 0,083 \\
Akses Bandara (X1) & 3,284 & 0,001 \\
Fasilitas dan Layanan Bandara (X2) & 0,892 & 0,375 \\
Fasilitas Restoran Bandara (X3) & 0,890 & 0,376 \\
Fasilitas Belanja Bandara (X4) & 0,885 & 0,378 \\
Personil Layanan dan Keamanan Bandara (X5) & 0,796 & 0,428 \\
Lingkungan Bandara (X6) & 3,883 & 0,000 \\
Layanan Imigrasi dan Bea Cukai Bandara (X7) & 3,868 & 0,000 \\
Dependent Variabel : Evaluasi Layanan Keseluruhan & & \\
\hline
\end{tabular}

Sumber : output SPSS 20.0, data primer yang diolah (2019)

Tabel 9

Hasil Uji t KLIA 2

\begin{tabular}{lcc}
\hline \multicolumn{1}{c}{ Model } & t & Sig. \\
\hline (constant) & 0,378 & 0,706 \\
Akses Bandara (X1) & 0,461 & 0,645 \\
Fasilitas dan Layanan Bandara (X2) & 2,995 & 0,000 \\
Fasilitas Restoran Bandara (X3) & 0,582 & 0,562 \\
Fasilitas Belanja Bandara (X4) & 0,293 & 0,770 \\
Personil Layanan dan Keamanan Bandara (X5) & 2,545 & 0,003 \\
Lingkungan Bandara (X6) & 1,126 & 0,263 \\
Layanan Imigrasi dan Bea Cukai Bandara (X7) & 2,424 & 0,003 \\
Dependent Variabel : Evaluasi Layanan Keseluruhan & & \\
\hline
\end{tabular}

Sumber : output SPSS 20.0, data primer yang diolah (2019)

Berdasarkan tabel 8 dan tabel 9 maka didapatkan hasil uji $\mathrm{t}$ untuk setiap variabel sebagai berikut :

(1) Akses Bandara

Untuk SHIA hasil t hitung Variabel akses bandara (X1) memiliki t hitung sebesar 3,284 dan nilai signifikansi 0,001 . Untuk KLIA 2 hasil hasil t hitung Variabel akses bandara (X1) memiliki t hitung sebesar 0,461 dan nilai signifikansi sebesar 0,645.
(2) Layanan dan Fasilitas Bandara Untuk SHIA hasil t hitung Variabel Kualitas Layanan dan Fasilitas Bandara (X2) memiliki $\mathrm{t}$ hitung sebesar 0,892 nilai signifikansi 0,375. Untuk KLIA 2 hasil t hitung Variabel Layanan dan Fasilitas bandara (X2) memiliki t hitung sebesar 2,995 dan nilai signifikansi 0,000.

(3) Fasilitas Restoran Bandara

Untuk SHIA hasil t hitung Variabel Fasilitas Restoran bandara (X3) memiliki t hitung 
sebesar 0,890 dan nilai signifikansi 0,375. Untuk KLIA 2 hasil t hitung Variabel Fasilitas Restoran bandara (X3) memiliki t hitung sebesar 0,582 dan nilai signifikansi 0,562 .

(4) Fasilitas Belanja Bandara

Untuk SHIA hasil t hitung Variabel Fasilitas Belanja bandara (X4) memiliki t hitung sebesar 0,885 dan nilai signifikansi 0,378. Untuk KLIA 2 tasil t hitung Variabel Fasilitas Belanja bandara (X4) memiliki t hitung sebesar 0,293 dan nilai signifikansi 0,770 .

(5) Personil Layanan dan Keamanan

Untuk SHIA hasil t hitung Variabel Personil Layanan dan Keamanan bandara (X5) memiliki t hitung sebesar 0,796 dan nilai signifikansi 0,428. Untuk KLIA 2 hasil t hitung Variabel Personil Layanan dan Keamanan bandara (X5) memiliki t hitung sebesar 2,545 dan nilai signifikansi 0,003.

(6) Lingkungan Bandara

Untuk SHIA hasil $\mathrm{t}$ hitung Variabel Lingkungan bandara (X6) memiliki t hitung sebesar 3,883 dan nilai signifikansi 0,000 .
Untuk KLIA 2 hasil t hitung Variabel Lingkungan bandara (X6) memiliki t hitung sebesar 1,126 dan nilai signifikansi 0,263.

(7) Layanan Imigrasi dan Bea Cukai

Untuk SHIA hasil t hitung Variabel Layanan Imigrasi dan Bea Cukai bandara (X7) memiliki t hitung sebesar 3,868 dan nilai signifikansi 0,000 . Untuk KLIA 2 hasil t hitung Variabel Layanan Imigrasi dan Bea Cukai bandara (X7) memiliki t hitung sebesar 2,424 dan nilai signifikansi 0,003.

\section{Hasil Uji secara simultan (uji f)}

Uji $F$ dilakukan untuk mengetahui apakah terdapat pengaruh kualitas akses bandara, layanan dan fasilitas bandra, fasilitas restoran bandara, fasilitas belanja bandara, personil layanan dan kemanan bandara, lingkungan bandara dan layanan imigrasi dan bea cukai secara bersama-sama (simultan) terhadap evaluasi pelayanan keseluruhan. Dengan nilai signifikansi 5\% maka f-tabel sebesar 2,0923. Berikut hasil uji F untuk SHIA dan KLIA 2 :

Tabel 10

Hasil Uji f SHIA

\begin{tabular}{|c|c|c|c|c|c|c|}
\hline Model & & $\begin{array}{c}\text { Sum of } \\
\text { Squares }\end{array}$ & Df & $\begin{array}{c}\text { Mean } \\
\text { Square }\end{array}$ & $\mathbf{F}$ & Sig. \\
\hline & Regression & 129,443 & 7 & 18,492 & 24,496 & $0,000^{\mathrm{b}}$ \\
\hline & Residual & 84,549 & 112 & 0,755 & & \\
\hline & Total & 213,992 & 119 & & & \\
\hline
\end{tabular}

Dependent Variabel : Evaluasi Layanan Keseluruhan

Predictors : (Constant), Akses Bandara, Fasilitas dan Layanan Bandara, Fasilitas

Restoran Bandara, Fasilitas Belanja Bandara, Personil Layanan dan Keamanan

Bandara, Lingkungan Bandara dan Layanan Imigrasi dan Bea Cukai Sumber: output SPSS 20.0, data primer yang diolah (2019)

Tabel 11

Hasil Uji f KLIA 2

\begin{tabular}{llrrrrr}
\hline Model & & \multicolumn{1}{c}{$\begin{array}{c}\text { Sum of } \\
\text { Squares }\end{array}$} & Df & \multicolumn{1}{c}{$\begin{array}{c}\text { Mean } \\
\text { Square }\end{array}$} & \multicolumn{1}{c}{ F } & Sig. \\
\hline & Regression & 254,646 & 7 & 36,378 & 12,731 & $0,000^{\mathrm{b}}$ \\
& Residual & 320,020 & 112 & 2,857 & & \\
Total & 574,667 & 119 & & & \\
\hline
\end{tabular}

Dependent Variabel : Evaluasi Layanan Keseluruhan

Predictors : (Constant), Akses Bandara, Fasilitas dan Layanan Bandara, Fasilitas

Restoran Bandara, Fasilitas Belanja Bandara, Personil Layanan dan Keamanan

Bandara, Lingkungan Bandara dan Layanan Imigrasi dan Bea Cukai

Sumber : output SPSS 20.0, data primer yang diolah (2019)

Berdasarkan hasil pengujian hipotesis secara simultan pada tabel 10 dan tabel 11 maka didapatkan hasil uji f yaitu, untuk SHIA, hasil f hitung sebesar 24,496 dan nilai signifikansi 
0,000.Untuk KLIA 2 hasil f hitung sebesar 12,731 dan nilai signifikansi 0,000 .

Koefisien determinasi

Koefisien determinasi $\left(\mathrm{R}^{2}\right)$ digunakan untuk mengukur seberapa jauh kemampuan model dalam menjelaskan variasi variabel dependen. Berikut ini koefisien determinasi SHIA dan KLIA 2 :

Tabel 12

Koefisien determinasi SHIA

\begin{tabular}{|c|c|c|c|c|c|c|c|c|c|}
\hline \multirow[b]{2}{*}{ Model } & \multirow[b]{2}{*}{$\mathbf{R}$} & \multirow[b]{2}{*}{$\begin{array}{c}\mathbf{R} \\
\text { Square }\end{array}$} & \multirow[b]{2}{*}{$\begin{array}{l}\text { Adjusted } \\
\text { R Square }\end{array}$} & \multirow{2}{*}{$\begin{array}{c}\text { Std. } \\
\text { Error of } \\
\text { the } \\
\text { Estimate }\end{array}$} & \multicolumn{5}{|c|}{ Change Statistic } \\
\hline & & & & & $\begin{array}{l}\text { R Square } \\
\text { Change }\end{array}$ & F Change & Df1 & Df2 & $\begin{array}{l}\text { Sig. F } \\
\text { Change }\end{array}$ \\
\hline 1 & $0,778^{\mathrm{a}}$ & 0,605 & 0,580 & 0,86885 & 0,605 & 24,496 & 7 & 112 & 0,000 \\
\hline
\end{tabular}

Dependent Variabel : Evaluasi Layanan Keseluruhan

Predictors : (Constant), Akses Bandara, Fasilitas dan Layanan Bandara, Fasilitas Restoran Bandara, Fasilitas Belanja Bandara, Personil Layanan dan Keamanan Bandara, Lingkungan Bandara dan Layanan Imigrasi dan Bea Cukai

Sumber : output SPSS 20.0, data primer yang diolah (2019)

Tabel 13

Koefisien determinasi KLIA 2

\begin{tabular}{|c|c|c|c|c|c|c|c|c|c|}
\hline \multirow[b]{2}{*}{ Model } & \multirow[b]{2}{*}{$\mathbf{R}$} & \multirow[b]{2}{*}{$\begin{array}{c}\mathbf{R} \\
\text { Square }\end{array}$} & \multirow[b]{2}{*}{$\begin{array}{l}\text { Adjusted } \\
\text { R Square }\end{array}$} & \multirow{2}{*}{$\begin{array}{c}\text { Std. } \\
\text { Error of } \\
\text { the } \\
\text { Estimate }\end{array}$} & \multicolumn{5}{|c|}{ Change Statistic } \\
\hline & & & & & $\begin{array}{c}\text { R Square } \\
\text { Change }\end{array}$ & F Change & Df1 & Df2 & $\begin{array}{l}\text { Sig. F } \\
\text { Change }\end{array}$ \\
\hline 1 & $0,666^{\mathrm{a}}$ & 0,543 & 0,408 & 1,69036 & 0,543 & 12,731 & 7 & 112 & 0,000 \\
\hline
\end{tabular}

Dependent Variabel : Evaluasi Layanan Keseluruhan

Predictors : (Constant), Akses Bandara, Fasilitas dan Layanan Bandara, Fasilitas Restoran Bandara, Fasilitas Belanja Bandara, Personil Layanan dan Keamanan Bandara, Lingkungan Bandara dan Layanan Imigrasi dan Bea Cukai

Sumber : output SPSS 20.0, data primer yang diolah (2019)

Tabel 14

Pedoman tingkat korelasi

\begin{tabular}{ll}
\hline Tingkat Hubungan & Interval Korelasi \\
\hline Sangat Rendah & $0,00-0,199$ \\
Rendah & $0,20-0,399$ \\
Sedang & $0,40-0,599$ \\
Kuat & $0,60-0,799$ \\
Sangat Kuat & $0,80-1,00$ \\
\hline
\end{tabular}

Sumber : Sugiyono (2011:183)

Berdasarkan tabel 12 dan 13 diatas, dapat diketahui hasil analisis regresi secara keseluruhan. Untuk SHIA memiliki Nilai $\mathrm{R}$ sebesar 0,778 menunjukan bahwa korelasi atau hubungan antara evaluasi pelayanan keseluruhan (variabel dependen) dengan kualitas akses bandara, layanan dan fasilitas bandara, fasilitas restoran bandara, fasilitas belanja bandara, personil layanan dan kemanan bandara, lingkungan bandara dan layanan imigrasi dan bea cukai (variabel independen) mempunyai tingkat hubungan yang kuat yaitu sebesar $77,8 \%$. Tingkat hubungan ini dilihat berdasarkan tabel pedoman untuk memberikan interpretasi koefisien korelasi (tabel 14). Nilai Adjusted $R$ Square adalah sebesar 0,580 menunjukan bahwa evaluasi pelayanan keseluruhan dipengaruhi oleh kualitas akses bandara, layanan dan fasilitas bandara, fasilitas restoran bandara, fasilitas belanja bandara, personil layanan dan kemanan bandara, lingkungan bandara dan layanan imigrasi dan bea cukai sebesar $58 \%$ selebihnya sebesar $42 \%$ 
dipengaruhi oleh sebab-sebab lain di luar penelitian ini.

Kemudian untuk KLIA 2 memiliki nilai $\mathrm{R}$ sebesar 0,666 menunjukan bahwa korelasi atau hubungan antara evaluasi pelayanan keseluruhan (variabel dependen) dengan kualitas akses bandara, layanan dan fasilitas bandara, fasilitas restoran bandara, fasilitas belanja bandara, personil layanan dan kemanan bandara, lingkungan bandara dan layanan imigrasi dan bea cukai (variabel independen) mempunyai tingkat hubungan yang kuat yaitu sebesar $66,6 \%$. Tingkat hubungan ini dilihat berdasarkan tabel pedoman untuk memberikan interpretasi koefisien korelasi (tabel 14). Nilai Adjusted $R$ Square sebesar 0,408, menunjukan bahwa evaluasi pelayanan keseluruhan dipengaruhi oleh kualitas akses bandara, layanan dan fasilitas bandara, fasilitas restoran bandara, fasilitas belanja bandara, personil layanan dan kemanan bandara, lingkungan bandara dan layanan imigrasi dan bea cukai sebesar $40,8 \%$ selebihnya sebesar $59,2 \%$ dipengaruhi oleh sebab-sebab lain di luar penelitian ini

\section{Analisis Respon Terbuka}

Analisis respon terbuka bertujuan untuk mengetahui peringkat tujuh kualitas layanan teratas di pertanyaan terbuka. Responden ditanyai pertanyaan berikut: "Di tempat yang disediakan di bawah, berikan umpan balik mengenai pengalaman Anda dengan (SHIA/KLIA 2). Anda dapat membagikan sesuatu yang positif atau negatif mengenai kualitas bandara". Ada 276 tanggapan dari total 120 responden (terdapat responden yang memberikan lebih dari 1 tanggapan) untuk tanggapan terhadap Soekarno Hatta International Airport (SHIA) dan terdapat 248 tanggapan untuk Kuala Lumpur International Airport 2 (KLIA 2). Dimana tanggapan ini akan dianalisis dan dikategorikan berdasarkan sifat umpan balik. Kategori mengikuti tujuh dimensi layanan bandara, yaitu akses bandar udara, layanan dan fasilitas bandar udara, fasilitas restoran atau tempat makan di bandar udara, fasilitas belanja bandar udara, personil layanan dan keamanan bandar udara, lingkungan bandar udara dan layanan imigrasi serta bea cukai.

Setiap tanggapan dikategorikan berdasarkan kesamaan dengan elemen layanan yang termasuk dalam survei $\left(\begin{array}{lll}7 & \text { dimensi }\end{array}\right.$ kualitas). Kategorisasi tanggapan tidak memperhitungkan apakah umpan baliknya negatif atau positif. Misalnya, umpan balik respons dapat berupa respons terbuka positif seperti, "Soekarno Hatta International Airport (SHIA) memiliki staf keamanan yang sopan" atau respons terbuka bersifat negatif seperti,"antrian pos keamanan Soekarno Hatta International Airport (SHIA) terlalu panjang". Dalam kedua kasus tersebut, kedua tanggapan termasuk dalam kategori personel layanan dan keamanan, karena keduanya membahas elemen layanan pos keamanan.

a. Hasil analisis respon terbuka SHIA

Tabel 15

Analisis Kuantitatif Pertanyaan Terbuka

\section{Peringkat Jumlah Respon Pertanyaan Terbuka}

Terbanyak

1. Personil Layanan dan Keamanan Bandara (75)

2. Fasilitas dan Layanan Bandara (67)

3. Lingkungan Bandara (52)

4. Layanan Imigrasi dan Bea Cukai (50)

5. Fasilitas Restoran Bandara (15)

6. Akses Bandara (13)

7. Fasilitas Belanja Bandara (4)

Sumber : data primer yang diolah (2019)

\begin{abstract}
Analisis tanggapan terhadap Soekarno Hatta International Airport (SHIA) memberikan peringkat pada tujuh dimensi kualitas layanan bandara. Peringkat pertama adalah Personil Layanan dan Keamanan Bandara dengan 75 tanggapan, kedua adalah
\end{abstract}

Fasilitas dan Layanan Bandara dengan 67 tanggapan, ketiga adalah Lingkungan Bandara dengan 52 tanggapan, keempat adalah Layanan Imigrasi dan Bea Cukai dengan 50 tanggapan, kelima adalah Fasilitas Restoran Bandara dengan 15 tanggapan, keenam adalah Akses 
Bandara dengan 13 tanggapan dan terakhir adalah Fasilitas Belanja Bandara dengan 4 tanggapan. Jadi diantara ketujuh dimensi kualitas pelayanan bandara kualitas personil layanan dan keamanan yang paling banyak ditanggapi oleh responden.

b. Hasil analisis respon terbuka KLIA 2

\section{Tabel 16}

Analisis Kuantitatif Pertanyaan Terbuka

\begin{tabular}{ll}
\hline \multicolumn{2}{c}{ Jumlah Respon Pertanyaan Terbuka Terbanyak } \\
\hline 1. & Personil Layanan dan Keamanan Bandara (76) \\
2. & Layanan Imigrasi dan Bea Cukai (57) \\
3. & Lingkungan Bandara (40) \\
4. & Fasilitas dan Layanan Bandara (34) \\
5. & Akses Bandara (26) \\
6. & Fasilitas Belanja Bandara (8) \\
7. & Fasilitas Restoran Bandara (7) \\
\hline
\end{tabular}

Sumber : data primer yang diolah (2019)

Analisis tanggapan terhadap Kuala Lumpur International Airport 2 (KLIA 2) memberikan peringkat pada tujuh dimensi kualitas layanan bandara. Peringkat pertama adalah Personil Layanan dan Keamanan Bandara dengan 76 tanggapan, kedua adalah Layanan Imigrasi dan Bea Cukai dengan 57 tanggapan, ketiga adalah Lingkungan Bandara dengan 40 tanggapan, keempat adalah Fasilitas dan Layanan Bandara dengan 34 tanggapan, kelima adalah Akses Bandara dengan 26 tanggapan, keenam adalah Fasilitas Belanja Bandara dengan 8 tanggapan dan terakhir adalah Fasilitas Restoran Bandara dengan 7 tanggapan. Jadi diantara ketujuh dimensi kualitas pelayanan bandara kualitas personil layanan dan keamanan yang paling banyak ditanggapi oleh responden.

\section{Analisis pilihan responden}

Berdasarkan analisis atas jawaban pertanyaan terbuka dimana sebelumnya responden diberikan pertanyaan untuk memberikan pilihan "Diantara Soekarno Hatta International Airport (SHIA) dan Kuala Lumpur International Airport 2 (KLIA 2) Malayasia menurut persepsinya manakah yang memiliki kualitas pelayanan lebih baik?". Berikut ini persentase hasil pilihan responden :

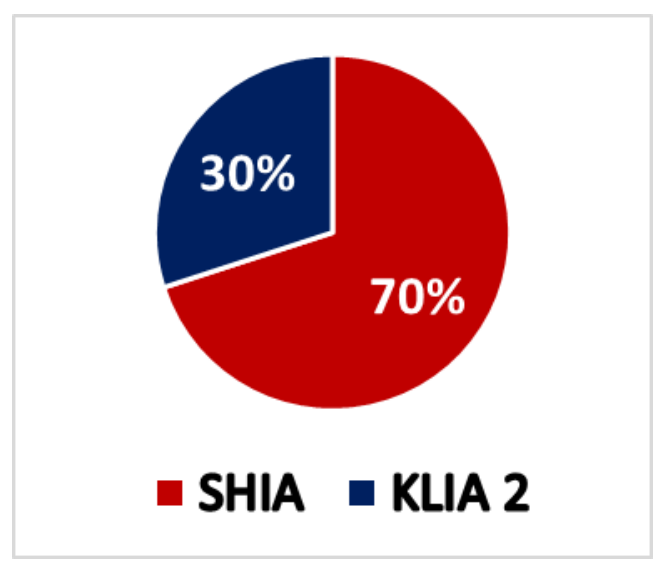

Gambar 5

Bandara pilihan responden

Sumber : data diolah (2019)

Dari total 120 responden sebanyak 70\% menyatakan Soekarno Hatta International Airport (SHIA) memiliki kualitas lebih baik dibanding Kuala Lumpur International Airport 2 (KLIA 2). Dan sebanyak 
30\% menyatakan Kuala Lumpur International Airport 2 (KLIA 2) memiliki kualitas lebih baik dibanding Soekarno Hatta International Airport (SHIA).

\section{Pembahasan}

a) Soekarno Hatta International Airport (SHIA)

1) Analisis Pengaruh Kualitas Akses Bandara Terhadap Evaluasi Pelayanan Keseluruhan Bandara

Untuk penelitian terhadap SHIA, penelitian ini berhasil membuktikan adanya Pengaruh Kualitas Akses Bandara Terhadap Evaluasi Pelayanan Keseluruhan Bandara. Hal ini dibuktikan dari hasil t hitung Variabel akses bandara (X1) memiliki t hitung sebesar 3,284 lebih besar daripada t tabel $(1,980)$ dan nilai signifikansi $(0,001)$ lebih kecil dari $(0,05)$ maka $\mathbf{H 1}$ diterima, yang artinya kualitas akses Bandara secara parsial berpengaruh positif signifikan terhadap evaluasi pelayanan keseluruhan. Sehingga kualitas layanan akses bandara dapat mempengaruhi penilaian responden terhadap bandara.

2) Analisis Pengaruh Kualitas Layanan dan Fasilitas Bandara Terhadap Evaluasi Pelayanan Keseluruhan Bandara Untuk penelitian terhadap SHIA, penelitian ini tidak berhasil membuktikan adanya Pengaruh Kualitas Layanan dan Fasilitas Bandara Terhadap Evaluasi Pelayanan Keseluruhan Bandara. Hal ini dibuktikan dari hasil $t$ hitung Variabel Kualitas Layanan dan Fasilitas Bandara (X2) memiliki t hitung sebesar 0,892 lebih kecil daripada $\mathrm{t}$ tabel $(1,980)$ dan nilai signifikansi $(0,375)$ lebih besar dari $(0,05)$ maka $\mathrm{H2}$ ditolak, yang artinya Kualitas Layanan dan Fasilitas Bandara secara parsial tidak berpengaruh positif signifikan terhadap evaluasi pelayanan keseluruhan. Sehingga kualitas layanan dan fasilitas bandara tidak mempengaruhi penilaian responden terhadap bandara.

3) Analisis Pengaruh Kualitas Fasilitas Restoran Bandara Terhadap Evaluasi Pelayanan Keseluruhan Bandara

Untuk penelitian terhadap SHIA, penelitian ini tidak berhasil membuktikan adanya Pengaruh Kualitas Fasilitas Restoran Bandara Terhadap Evaluasi Pelayanan Keseluruhan Bandara. Hal ini dibuktikan dari hasil $t$ hitung Variabel Fasilitas Restoran bandara (X3) memiliki t hitung sebesar 0,890 lebih kecil daripada t tabel $(1,980)$ dan nilai signifikansi $(0,375)$ lebih besar dari $(0,05)$ maka $\mathbf{H 3}$ ditolak, yang artinya kualitas Fasilitas Restoran Bandara secara parsial tidak berpengaruh positif signifikan terhadap evaluasi pelayanan keseluruhan. Sehingga kualitas layanan restoran tidak dapat mempengaruhi penilaian responden terhadap bandara.

4) Analisis Pengaruh Kualitas Fasilitas Belanja Bandara Terhadap Evaluasi Pelayanan Keseluruhan Bandara

Untuk penelitian terhadap SHIA, penelitian ini tidak berhasil membuktikan adanya Pengaruh Kualitas Fasilitas Belanja Bandara Bandara Terhadap Evaluasi Pelayanan Keseluruhan Bandara. Hal ini dibuktikan dari hasil $\mathrm{t}$ hitung Variabel Fasilitas Belanja bandara (X4) memiliki t hitung sebesar 0,885 lebih kecil daripada $\mathrm{t}$ tabel $(1,980)$ dan nilai signifikansi $(0,378)$ lebih besar dari $(0,05)$ maka H4 ditolak, yang artinya kualitas Fasilitas Belanja Bandara secara parsial tidak berpengaruh positif signifikan terhadap evaluasi pelayanan keseluruhan. Sehingga kualitas layanan belanja tidak dapat mempengaruhi penilaian responden terhadap bandara.

5) Analisis Pengaruh Kualitas Personil Layanan dan Keamanan Bandara Terhadap Evaluasi Pelayanan Keseluruhan Bandara

Untuk penelitian terhadap SHIA, penelitian ini tidak berhasil membuktikan adanya Pengaruh Kualitas Personil Layanan dan Keamanan Bandara Terhadap Evaluasi Pelayanan Keseluruhan Bandara. Hal ini dibuktikan dari hasil $\mathrm{t}$ hitung Variabel Personil Layanan dan Keamanan bandara (X5) memiliki t hitung sebesar 0,796 lebih kecil daripada $\mathrm{t}$ tabel $(1,980)$ dan nilai signifikansi $(0,428)$ lebih besar dari $(0,05)$ maka $H 5$ ditolak, yang artinya kualitas Personil Layanan dan Keamanan Bandara secara parsial tidak berpengaruh positif signifikan terhadap evaluasi pelayanan keseluruhan. Sehingga kualitas layanan personil dan keamanan tidak dapat mempengaruhi penilaian responden terhadap bandara. 
6) Analisis Pengaruh Kualitas Lingkungan Bandara Terhadap Evaluasi Pelayanan Keseluruhan Bandara

Untuk penelitian terhadap SHIA, penelitian ini berhasil membuktikan adanya Pengaruh Kualitas Lingkungan Bandara Terhadap Evaluasi Pelayanan Keseluruhan Bandara. Hal ini dibuktikan dari hasil $\mathrm{t}$ hitung Variabel Lingkungan bandara (X6) memiliki t hitung sebesar 3,883 lebih besar daripada $\mathrm{t}$ tabel $(1,980)$ dan nilai signifikansi $(0,000)$ lebih kecil dari $(0,05)$ maka $\mathrm{H6}$ diterima, yang artinya kualitas lingkungan Bandara secara parsial berpengaruh positif signifikan terhadap evaluasi pelayanan keseluruhan. Sehingga kualitas lingkungan bandara dapat mempengaruhi penilaian responden terhadap bandara.

7) Analisis Pengaruh Kualitas Layanan Imigrasi dan Bea Cukai Bandara Terhadap Evaluasi Pelayanan Keseluruhan Bandara

Untuk penelitian terhadap SHIA, penelitian ini berhasil membuktikan adanya Pengaruh Kualitas Layanan Imigrasi dan Bea Cukai Bandara Terhadap Evaluasi Pelayanan Keseluruhan Bandara. Hal ini dibuktikan dari hasil $t$ hitung Variabel Layanan Imigrasi dan Bea Cukai bandara (X7) memiliki t hitung sebesar 3,868 lebih besar daripada $\mathrm{t}$ tabel $(1,980)$ dan nilai signifikansi $(0,000)$ lebih kecil dari $(0,05)$ maka $\mathbf{H 7}$ diterima, yang artinya kualitas Layanan Imigrasi dan Bea Cukai Bandara secara parsial berpengaruh positif signifikan terhadap evaluasi pelayanan keseluruhan. Sehingga kualitas laynan imigrasi dan bea cukai dapat mempengaruhi penilaian responden terhadap bandara.

Adanya variabel-variabel yang tidak berpengaruh disebabkan karena penelitian ini hanya berdasarkan persepsi mahasiswa peserta KKL STIE Sutaatmadja. Persepsi seseorang terhadap suatu objek dapat berbeda dengan orang lain. Perbedaan tersebut dipengaruhi oleh berbagai faktor. Cara kita mempersepsikan situasi sekarang tidak bisa terlepas dari adanya pengalaman sensoris terdahulu (Dimyati, 1990:41). Sehingga tidak menutup kemungkinan terjadi perbedaan penilaian antara satu pihak dan pihak lainnya. Menurut Sarlito (1996:43-44), menyatakan bahwa terdapat beberapa faktor yang menyebabkan perbedaan persepsi yaitu :
a) Perhatian.

Biasanya seseorang tidak menangkap seluruh rangsang yang ada di sekitar secara sekaligus, tetapi hanya memfokuskan perhatian pada satu atau dua obyek saja. Perbedaan fokus antara satu orang dengan orang lainnya menyebabkan perbedaan persepsi (Sarlito, 1996:43-44). Oleh karena itu, ketika responden berada di SHIA responden cenderung terfokus pada kualitas akses bandara, kondisi lingkungan bandara dan kualitas pelayanan imigrasi dan bea cukai yang diterima responden, dan tidak terlalu memperhatikan ke empat dimensi kualitas layanan lainnya. Sehingga ketiga dimensi kualitas tersebut yang paling berpengaruh terhadap penliaian responden terhadap kualitas bandara keseluruhan.

b) Kebutuhan

Kebutuhan baik sesaat maupun yang menetap pada diri seseorang akan mempengaruhi persepsi seseorang. Kebutuhan yang berbeda akan menyebabkan persepsi yang berbeda pula. (Sarlito, 1996:43-44). Responden dalam penelitian ini merupakan mahasiswa yang akan melaksanakan program KKL dan sebagian besar belum pernah mengunjungi bandara. Kebutuhan antara penumpang yang akan melakukan perjalanan bisnis atau liburan dengan mahasiswa peserta KKL STIE Sutaatmadja memiliki kebutuhan yang berbeda. Mahasiswa peserta KKL hanya menggunakan bandara sebagai tempat untuk menaiki pesawat, sedangkan penumpang yang akan melakukan perjalanan bisnis atau liburan tentunya memiliki kebutuhan yang lebih dibanding mahasiswa peserta KKL, biasanya para pelancong bisnis maupun pelancong yang akan berlibur banyak menghabiskan waktu tunggu di bandara untuk bekerja, makan dan berbelanja (Pudjo,2009). Oleh karena itu terjadi perbedaan pengaruh dimensi kualitas yaitu dimensi fasilitas restoran dan fasilitas belanja disebabkan karena perbedaan kebutuhan.

Sedangkan secara simultan, terdapat pengaruh antara ketujuh dimensi kualitas layanan bandara dengan evaluasi layanan secara keseluruhan. Hal ini dibuktikan dari hasil $\mathrm{f}$ hitung sebesar 24,496 lebih besar daripada $\mathrm{f}$ tabel $(2,0923)$ dan nilai signifikansi $(0,000)$ lebih kecil dari $(0,05)$ maka $\mathbf{H 8}$ diterima, yang artinya kualitas Akses Bandara, Layanan dan Fasilitas Bandara, Fasilitas Restoran Bandara, Fasilitas Belanja Bandara, Personil Layanan 
dan Keamanan Bandara, Lingkungan Bandara dan Layanan Imigrasi dan Bea Cukai Bandara secara simultan berpengaruh positif signifikan terhadap evaluasi pelayanan keseluruhan. Sehingga ketujuh atribut kualitas pelayanan tersebut menjadi faktor penentu persepsi mahasiswa dalam menilai kualitas SHIA secara keseluruhan.

\section{b) Kuala Lumpur International Airport 2} (KLIA 2)

1) Analisis Pengaruh Kualitas Akses Bandara Terhadap Evaluasi Pelayanan Keseluruhan Bandara

Untuk penelitian terhadap KLIA 2, penelitian ini tidak berhasil membuktikan adanya Pengaruh Kualitas Akses Bandara Terhadap Evaluasi Pelayanan Keseluruhan Bandara. Hal ini dibuktikan dari hasil $t$ hitung Variabel akses bandara (X1) memiliki t hitung sebesar 0,461 dan nilai signifikansi sebesar 0,645. Karena nilai t hitung $(0,461)$ lebih kecil dari $t$ tabel $(1,980272)$ dan nilai signifikansi $(0,645)$ lebih besar dari $(0,05)$ maka H1 ditolak, yang artinya kualitas akses Bandara secara parsial tidak berpengaruh positif signifikan terhadap evaluasi pelayanan keseluruhan. Sehingga kualitas layanan akses bandara tidak dapat mempengaruhi penilaian responden terhadap bandara.

2) Analisis Pengaruh Kualitas Layanan dan Fasilitas Bandara Terhadap Evaluasi Pelayanan Keseluruhan Bandara

Untuk penelitian terhadap KLIA 2, penelitian ini berhasil membuktikan adanya Pengaruh Kualitas Layanan dan Fasilitas Bandara Terhadap Evaluasi Pelayanan Keseluruhan Bandara. Hal ini dibuktikan dari hasil t hitung Variabel Layanan dan Fasilitas bandara (X2) memiliki t hitung sebesar 2,995 lebih besar dari $t$ tabel $(1,980272)$ dan nilai signifikansi $(0,000)$ lebih kecil dari $(0,05)$ maka $\mathbf{H 2}$ diterima, yang artinya kualitas Layanan dan Fasilitas Bandara secara parsial berpengaruh positif signifikan terhadap evaluasi pelayanan keseluruhan. Sehingga kualitas layanan dan fasilitas bandara dapat mempengaruhi penilaian responden terhadap bandara.

3) Analisis Pengaruh Kualitas Fasilitas Restoran Bandara Terhadap Evaluasi Pelayanan Keseluruhan Bandara
Untuk penelitian terhadap KLIA 2, penelitian ini tidak berhasil membuktikan adanya Pengaruh Kualitas Fasilitas Restoran Bandara Terhadap Evaluasi Pelayanan Keseluruhan Bandara. Hal ini dibuktikan dari hasil $\mathrm{t}$ hitung Variabel Fasilitas Restoran bandara (X3) memiliki t hitung sebesar 0,582 lebih kecil dari t tabel $(1,980272)$ dan nilai signifikansi $(0,562)$ lebih besar dari $(0,05)$ maka $\mathbf{H 3}$ ditolak, yang artinya kualitas Fasilitas Restoran Bandara secara parsial tidak berpengaruh positif signifikan terhadap evaluasi pelayanan keseluruhan. Sehingga kualitas layanan restoran tidak dapat mempengaruhi penilaian responden terhadap bandara.

4) Analisis Pengaruh Kualitas Fasilitas Belanja Bandara Terhadap Evaluasi Pelayanan Keseluruhan Bandara

Untuk penelitian terhadap KLIA 2, penelitian ini tidak berhasil membuktikan adanya Pengaruh Kualitas Fasilitas Belanja Bandara Terhadap Evaluasi Pelayanan Keseluruhan Bandara. Hal ini dibuktikan dari hasil t hitung Variabel Fasilitas Belanja bandara (X4) memiliki t hitung sebesar 0,293 lebih kecil dari t tabel $(1,980272)$ dan nilai signifikansi $(0,770)$ lebih besar dari $(0,05)$ maka H4 ditolak, yang artinya kualitas Fasilitas Belanja Bandara secara parsial tidak berpengaruh positif signifikan terhadap evaluasi pelayanan keseluruhan. Sehingga kualitas layanan belanja tidak dapat mempengaruhi penilaian responden terhadap bandara.

5) Analisis Pengaruh Kualitas Personil Layanan dan Keamanan Bandara Terhadap Evaluasi Pelayanan Keseluruhan Bandara

Untuk penelitian terhadap KLIA 2, penelitian ini berhasil membuktikan adanya Pengaruh Kualitas Personil Layanan dan Keamanan Bandara Terhadap Evaluasi Pelayanan Keseluruhan Bandara. Hal ini dibuktikan dari hasil $\mathrm{t}$ hitung Variabel Personil Layanan dan Keamanan bandara (X5) memiliki t hitung sebesar 2,545 lebih besarl dari $\mathrm{t}$ tabel $(1,980272)$ dan nilai signifikansi $(0,003)$ lebih kecil dari $(0,05)$ maka H5 diterima, yang artinya kualitas Personil Layanan dan Keamanan Bandara secara parsial berpengaruh positif signifikan terhadap evaluasi pelayanan keseluruhan. Sehingga kualitas layanan dan 
keamanan dapat mempengaruhi penilaian responden terhadap bandara.

6) Analisis Pengaruh Kualitas Lingkungan Bandara Terhadap Evaluasi Pelayanan Keseluruhan Bandara

Untuk penelitian terhadap KLIA 2, penelitian ini tidak berhasil membuktikan adanya Pengaruh Kualitas Lingkungan Bandara Terhadap Evaluasi Pelayanan Keseluruhan Bandara. Hal ini dibuktikan dari hasil $\mathrm{t}$ hitung Variabel Lingkungan bandara (X6) memiliki t hitung sebesar 1,126 lebih kecil dari $t$ tabel $(1,980272)$ dan nilai signifikansi $(0,263)$ lebih besar dari $(0,05)$ maka $H 6$ ditolak, yang artinya kualitas Lingkungan Bandara secara parsial tidak berpengaruh positif signifikan terhadap evaluasi pelayanan keseluruhan. Sehingga kualitas lingkungan bandara tidak dapat mempengaruhi penilaian responden terhadap bandara.

7) Analisis Pengaruh Kualitas Layanan Imigrasi dan Bea Cukai Bandara Terhadap Evaluasi Pelayanan Keseluruhan Bandara

Untuk penelitian terhadap KLIA 2, penelitian ini berhasil membuktikan adanya Pengaruh Kualitas Layanan Imigrasi dan Bea Cukai Bandara Terhadap Evaluasi Pelayanan Keseluruhan Bandara. Hal ini dibuktikan dari hasil $t$ hitung Variabel Layanan Imigrasi dan Bea Cukai bandara (X7) memiliki t hitung sebesar 2,424 lebih kecil dari $\mathrm{t}$ tabel $(1,980272)$ dan nilai signifikansi $(0,003)$ lebih kecil dari $(0,05)$ maka $\mathbf{H 7}$ diterima, yang artinya kualitas Layanan Imigrasi dan Bea Cukai Bandara secara parsial berpengaruh positif signifikan terhadap evaluasi pelayanan keseluruhan. Sehingga kualitas layanan imigrasi dan bea cukai dapat mempengaruhi penilaian responden terhadap bandara.

Adanya faktor-faktor yang tidak berpengaruh disebabkan karena penelitian ini berdasarkan persepsi mahasiswa peserta KKL STIE Sutaatmadja. Persepsi seseorang terhadap suatu objek dapat berbeda dengan orang lain. Perbedaan tersebut dipengaruhi oleh berbagai faktor. Cara kita mempersepsikan situasi sekarang tidak bisa terlepas dari adanya pengalaman sensoris terdahulu (Dimyati, 1990:41). Sehingga tidak menutup kemungkinan terjadi perbedaan penilaian antara satu pihak dan pihak lainnya. Menurut Sarlito
(1996:43-44), menyatakan bahwa terdapat beberapa faktor yang menyebabkan perbedaan persepsi yaitu:

a) Perhatian.

Biasanya seseorang tidak menangkap seluruh rangsang yang ada di sekitar secara sekaligus, tetapi hanya memfokuskan perhatian pada satu atau dua obyek saja. Perbedaan fokus antara satu orang dengan orang lainnya menyebabkan perbedaan persepsi (Sarlito, 1996:43-44). Oleh karena itu, ketika responden berada di KLIA 2 responden cenderung terfokus pada kualitas layanan dan fasilitas bandara, personil layanan dan keamanan bandara serta layanan imigrasi yang diterima responden, dan tidak terlalu memperhatikan ke empat dimensi kualitas layanan lainnya. Sehingga ketiga dimensi kualitas tersebut yang paling berpengaruh terhadap penliaian responden terhadap kualitas bandara keseluruhan. Sedangkan untuk variabel lainnya seperti akses bandara, fasilitas restoran bandara, fasilitas belanja bandara dan lingkungan tidak terlalu menarik perhatian responden sehingga tidak berpengaruh terhadap penliaian responden terhadap kualitas bandara keseluruhan.

b) Kebutuhan

Kebutuhan baik sesaat maupun yang menetap pada diri seseorang akan mempengaruhi persepsi seseorang. Kebutuhan yang berbeda akan menyebabkan persepsi yang berbeda pula. (Sarlito, 1996:43-44). Responden dalam penelitian ini merupakan mahasiswa yang akan melaksanakan program KKL dan sebagian besar belum pernah mengunjungi bandara. Kebutuhan antara penumpang yang akan melakukan perjalanan bisnis atau liburan dengan mahasiswa peserta KKL STIE Sutaatmadja memiliki kebutuhan yang berbeda. Mahasiswa peserta KKL hanya menggunakan bandara sebagai tempat untuk menaiki pesawat, sedangkan penumpang yang akan melakukan perjalanan bisnis atau liburan tentunya memiliki kebutuhan yang lebih dibanding mahasiswa peserta KKL, biasanya para pelancong bisnis maupun pelancong yang akan berlibur banyak menghabiskan waktu tunggu di bandara untuk bekerja, makan dan berbelanja (Pudjo,2009). Oleh karena itu terjadi perbedaan pengaruh dimensi kualitas yaitu dimensi fasilitas restoran dan fasilitas belanja disebabkan karena perbedaan kebutuhan.

Sedangkan Secara simultan terdapat pengaruh antara ketujuh dimensi kualitas 
layanan bandara dengan evaluasi layanan secara keseluruhan. Hal ini dibuktikan dari hasil $\mathrm{f}$ hitung sebesar 12,731 lebih besar daripada $\mathrm{f}$ tabel $(2,0923)$ dan nilai signifikansi $(0,000)$ lebih kecil dari $(0,05)$ maka $\mathbf{H 8}$ diterima, yang artinya kualitas Akses Bandara, Layanan dan Fasilitas Bandara, Fasilitas Restoran Bandara, Fasilitas Belanja Bandara, Personil Layanan dan Keamanan Bandara, Lingkungan Bandara dan Layanan Imigrasi dan Bea Cukai Bandara secara simultan berpengaruh positif signifikan terhadap evaluasi pelayanan keseluruhan.

Sehingga ketujuh atribut kualitas pelayanan menjadi faktor penentu persepsi mahasiswa dalam menilai kualitas KLIA 2 secara keseluruhan.

\section{c) Perbandingan penilaian kualitas SHIA} dan KLIA 2 menurut persepsi responden

Berdasarkan persepsi mahasiswa peserta KKL STIE Sutaatmadja tahun ajaran 2018/2019 sebanyak $70 \%$ dari total 120 peserta KKL menyatakan bahwa SHIA memiliki kualitas pelayanan yang lebih baik dibanding KLIA 2 . Dan hanya $30 \%$ responden yang menyatakan KLIA 2 memiliki kualitas pelayanan lebih baik dibanding SHIA. Adanya perbedaan penilaian tersebut karena, penelitian ini hanya berdasarkan persepsi mahasiswa peserta KKL STIE Sutaatmadja berdasarkan hasil evaluasinya terhadap 7 dimensi kualitas pelayanan bandara di kedua bandara tersebut. Persepsi seseorang terhadap suatu objek dapat berbeda dengan orang lain. Perbedaan tersebut dipengaruhi oleh berbagai faktor. Cara kita mempersepsikan situasi sekarang tidak bisa terlepas dari adanya pengalaman sensoris terdahulu (Dimyati, 1990:41). Sehingga tidak menutup kemungkinan terjadi perbedaan penilaian antara satu pihak dan pihak lainnya. Sarlito (1996:43-44), menyatakan bahwa salah satu faktor yang menyebabkan perbedaan persepsi yaitu set/ekspektasi. Set adalah harapan seseorang terhadap rangsang yang akan diterima. (Sarlito, 1996:43-44). Perbedaan harapan ini dapat mempengaruhi persepsi responden dalam menilai kualitas layanan bandara. Adanya perbedaan penilaian responden dimana sebanyak $70 \%$ menyatakan SHIA memiliki kualitas lebih baik dibanding KLIA 2 dan $30 \%$ lainnya menyatakan sebaliknya yaitu KLIA 2 memiliki kualitas lebih baik. Disebabkan karena setiap responden memiliki harapan atau ekspektasi yang berbeda terhadap layanan yang akan diterima dari SHIA maupun KLIA 2. Ketika responden menerima pelayanan secara langsung, pelayanan yang diterima tersebut dapat sesuai atau berbeda dengan ekspektasi. Perbedaan antara harapan dan realita yang diterima yang menyebabkan adanya perbedaan pilihan. Kemungkinan $70 \%$ responden yang menyatakan SHIA memiliki kualitas lebih baik dibanding KLIA 2 merasakan bahwa pelayanan di SHIA lebih sesuai dengan harapannya sedangkan $30 \%$ lainnya merasakan bahwa pelayanan di KLIA 2 lebih sesuai dengan harapannya.

\section{PENUTUP}

Kesimpulan

Berdasarkan hasil analisis data dan pembahasan, maka kesimpulan yang dapat diambil dalam penelitian ini adalah :

1. Untuk penilaian kualitas pelayanan di Soekarno Hatta International Airport (SHIA). Secara parsial penelitian ini menunjukan bahwa ditemukan adanya pengaruh yang positif signifikan antara variabel kualitas akses bandara, lingkungan bandara dan layanan imigrasi dan bea cukai dengan variabel evaluasi pelayanan keseluruhan. Sedangkan untuk variabel kualitas layanan dan fasilitas bandara, fasilitas restoran bandara, fasilitas belanja bandara dan personil layanan dan keamanan bandara tidak ditemukan adanya pengaruh yang positif signifikan terhadap variabel evaluasi pelayanan keseluruhan. Kemudian secara simultan hasil penelitian ini menunjukan bahwa ditemukan adanya pengaruh yang signifikan antara dimensi kualitas pelayanan (akses bandara, layanan dan fasilitas bandara, fasilitas restoran atau tempat makan di bandara, fasilitas belanja bandara, personil layanan dan keamanan bandara, lingkungan bandara dan layanan imigrasi serta bea cukai) secara bersamasama terhadap evaluasi layanan keseluruhan.

2. Untuk penilaian kualitas pelayanan di Kuala Lumpur International Airport 2 (KLIA 2). Secara parsial penelitian ini menunjukan bahwa ditemukan adanya pengaruh yang positif signifikan antara variabel kualitas layanan dan fasilitas bandara, personil layanan dan keamanan bandara bandara dan layanan imigrasi dan bea cukai dengan evaluasi pelayanan keseluruhan. Sedangkan untuk variabel kualitas akses bandara, fasilitas restoran 
bandara, fasilitas belanja bandara dan lingkungan bandara tidak ditemukan adanya pengaruh yang positif signifikan terhadap variabel evaluasi pelayanan keseluruhan. Kemudian secara simultan hasil penelitian ini menunjukan bahwa ditemukan adanya pengaruh yang signifikan antara dimensi kualitas pelayanan (akses bandara, layanan dan fasilitas bandara, fasilitas restoran atau tempat makan di bandara, fasilitas belanja bandara, personil layanan dan keamanan bandara, lingkungan bandara dan layanan imigrasi serta bea cukai) secara bersamasama terhadap evaluasi layanan keseluruhan.

3. Berdasarkan persepsi mahasiswa peserta KKL STIE Sutaatmadja tahun ajaran 2018/2019 sebanyak 70\% dari total 120 peserta KKL menyatakan bahwa Soekarno Hatta International Airport (SHIA) memiliki kualitas pelayanan yang lebih baik dibanding Kuala Lumpur International Airport 2 (KLIA 2) Malaysia. Dan hanya $30 \%$ responden yang menyatakan KLIA 2 memiliki kualitas lebih baik dibanding SHIA.

\section{Batasan Penelitian}

Batasan penelitian ini adalah sebagai berikut :

1. Penelitian ini dilakukan hanya berdasarkan sudut pandang penumpang (Mahasiswa Peserta KKL STIE Sutaatmadja tahun ajaran 2018/2019) sehingga jumlah sampel hanya sebanyak 120 responden.

2. Penelitian ini hanya mengevaluasi 7 dimensi kualitas diantaranya; akses bandara, layanan dan fasilitas bandara, fasilitas restoran atau tempat makan di bandara, fasilitas belanja bandara, personil layanan dan keamanan bandara, lingkungan bandara dan layanan imigrasi serta bea cukai.

3. Analisis perbandingan antara kualitas pelayanan antara Soekarno Hatta International Airport (SHIA) maupun Kuala Lumpur International Airport 2 (KLIA 2) hanya berdasarkan persepsi mahasiswa peserta KKL STIE Sutaatmadja tahun ajaran 2018/2019.

\section{Saran}

Saran untuk penelitian selanjutnya yaitu :

1. Pada penelitian selanjutnya sebaiknya dapat menambahkan responden dengan latar belakang yang lebih bervariasi tidak hanya terbatas pada mahasiswa. Penumpang dengan latar belakang melakukan perjalanan bisnis atau perjalanan liburan kemungkinan dapat memberikan hasil yang berbeda karena terdapat perbedaan kepentingan dan kebutuhan.

2. Pada penelitian selanjutnya dapat menambah kualitas dimensi lain yang dapat dinilai selain menilai berdasarkan 7 dimensi kualitas seperti yang dilakukan dalam penelitian ini.

3. Pada penelitian selanjutnya dapat memperluas populasi dan menambah jumlah sampel sehingga hasil penelitian lebih komprehensif lagi.

\section{DAFTAR PUSTAKA}

Dabholkar, P. A., Thorpe, D. I., \& Rentz, J. O. (1995). A measure of service quality for retail stores: Scale development and validation. Journal of the Academy of Marketing Science, 24(1), 3-16.

Dhio, Darus.M dan Kasyful, Mahalli. (2012). Analisis Tingkat Kepuasan Penumpang Terhadap Kualitas Pelayanan di Bandara Intenasional Kualanmu. Jurnal Ekonomi dan Keuangan. Vol 3, No 6.

Dimyati, Mahmud. (1990). Psikologi Suatu Pengantar. Jakarta : BPFE

Fodness, D., Muray, B. (2007). Pasenggers' Expectations of Airport Service Quality. Journal of Service Marketing. 21/7, 492-506. Emerald Group Publishing Limited.

Ghozali, Imam. (2005). Aplikasi Analisis Multivariate Dengan Program SPSS. Semarang : Universitas Diponegoro

http://hubud.dephub.go.id/?id/page/detail/44.20 14 (diakses pada 14 Agustus 2019)

https://aci.aero/news/2019/03/13/preliminaryworld-airport-traffic-rankings-released/ (diakses pada 14 Agustus 2019)

https://www.worldairportawards.com/worldstop-100-airports-2018/ (diakses pada 14 Agustus 2019)

https://www.statistikian.com/2014/04/mannwhitney-u-test.html/amp (diakses pada 18 September 2019) 
Ida, Nuraida., Vicentia, Wahju. W., Lilian, Danil. (2015). Kualitas Pelayanan dan Kepuasan Konsumen di Bandara Internasional Soekarno-Hatta. Bandung, 2015.

Keputusan Menteri Perhubungan No. 48 tahun 2002 tentang Penyelenggaraan Bandara Umum

Kotler, Philip dan Kevin Lane Keller. (2003). Manajemen Pemasaran. Jakarta : PT. Indeks

Majid, Suharto Abdul dan Warpani, Eko Probo D. (2009). Ground Handling Manajemen Pelayanan Darat Perusahaan Penerbangan. Jakarta : Rajawali Pers

Majid, Suharto Abdul. (2009). Costumer Service dalam Bisnis Jasa Transportasi. Jakarta : Rajawali Pers

Maulana, Aditya. W. Pengaruh Kualitas Pelayanan Terhadap Kepuasan Pelanggan Terminal 3 Bandara Soekarno-Hatta. Serang, 2017.

Miftah, Thoha. (2003). Perilaku Organisasi : Konsep Dasar dan Aplikasinya. Jakarta : PT. Raya Grafindo Persada

Nasution, M.N. (2005). Manajemen Mutu Terpadu. Ghalia Indonesia.

Parasuraman, A., VA, Zaithaml dan LL., Berry. (1985). A Conceptual Model of Service Quality and its Implication for Future Research. Vol. 49. Journal of Marketing.

Parasuraman, A., VA, Zaithaml dan LL., Berry. (1990). Delivering Quality Service. New York: The Free Press A. Division of Macmilan Inc.

Parasuraman, A., Zeithaml, V. A., \& Berry, L. L. (1988). SERVQUAL: A multipleitem scale for measuring consumer perceptions of service quality. Journal of Retailing, 64(1), 12-40.

Parasuraman, A., Zeithaml, V.A. , \& Berry, L.L. (1994). Alternative scales for measuring service quality: $A$ comparative assessment based on psychometric and diagnostic criteria. Journal of Retailing, 70(3),201-230.

Parasuraman, A., Zeithaml, V.A., \& Berry, L.L. (1991). Refinement and reassessment of the SERVQUAL Scale. Journal of Retailing, 67(4), 420-500.

Peraturan Pemerintah Republik Indonesia Nomor 70 tahun 2001
Pudjo, Karsono. (2009). Analisis Kualitas Pelayanan Terhadap Tingkat Kepuasan Pelanggan Calon Pengguna Jasa Penerbangan Domestik Bandara Soekarno Hatta. Jurnal Ilmiah Aviasi Langit Biru. Vol. 2, No. 3.

Rangkuti, Freddy. (2003). Riset Pemasaran. Jakarta : PT. Gramedia Pustaka Utama

Redha Widarsyah. The Impact of Airport Service Quality Dimensions on Overall Airport Experience and Impressions. Nevada Las Vegas, 2013.

Sekaran, U. (1992). Research Methods for Business : A Skill Building Approach. $2^{\text {nd }}$ ed. New York, Jhon Wiley \& Sons Inc.

Sugiyono. (2011). Metode Penelitian Bisnis. Bandung : Alfabeta

Supranto, J. (2006). Pengukuran Tingkat Kepuasan Pelayanan. Jakrta : PT. Temata Cipta.

Tjiptono, Fandi. (2002). Strategi Pemasaran. Yogjakarta : Andi Offset.

Tjiptono, Fandi. (2005). Manajemen Jasa. Yogjakarta : Andi Offset.

Tjiptono, Fandi. (2007). Service, Quality \& Satisfaction. Yogjakarta : Andi Offset.

Yamit, Zulian. (2001). Manajemen Produksi dan Operasi. Yogyakarta : Ekomisia.

Zeithaml, V.A., Berry, L.L dan Parasuraman, A. (1993). The Nature and Determinants of Costumer Expectations of Service. Vol. 21. Journal of The Academy of Marketing Science.

Zeithaml, Valerie., Bitner M.J., Germler D. (2006). Service Marketing, Integrating Customer Focus Across The Firm. $4^{\text {th }}$ ed. New York, Mc Graw Hill Company Inc. 